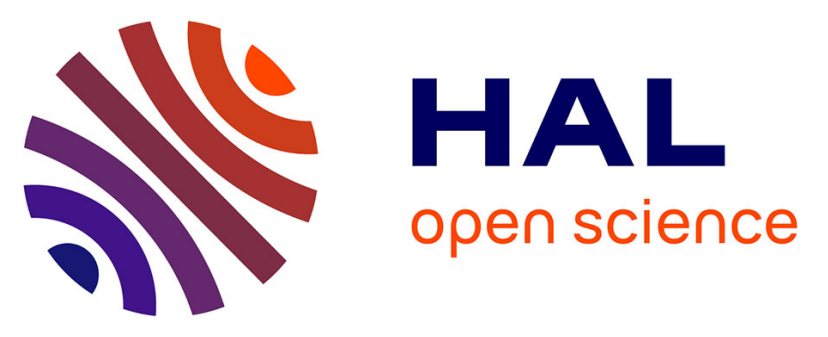

\title{
Discovery of azaisoerianin derivatives as potential antitumors agents
}

Mohamed Ali Soussi, Olivier Provot, Guillaume Bernadat, Jérôme Bignon, Joanna Wdzieczak-Bakala, Déborah Desravines, Joëlle Dubois, Jean-Daniel Brion, Samir Messaoudi, Mouad Alami

\section{To cite this version:}

Mohamed Ali Soussi, Olivier Provot, Guillaume Bernadat, Jérôme Bignon, Joanna Wdzieczak-Bakala, et al.. Discovery of azaisoerianin derivatives as potential antitumors agents. European Journal of Medicinal Chemistry, 2014, 78, pp.178-189. 10.1016/j.ejmech.2014.03.032 . hal-02394376

\section{HAL Id: hal-02394376 https://hal.science/hal-02394376}

Submitted on 4 Dec 2019

HAL is a multi-disciplinary open access archive for the deposit and dissemination of scientific research documents, whether they are published or not. The documents may come from teaching and research institutions in France or abroad, or from public or private research centers.
L'archive ouverte pluridisciplinaire HAL, est destinée au dépôt et à la diffusion de documents scientifiques de niveau recherche, publiés ou non, émanant des établissements d'enseignement et de recherche français ou étrangers, des laboratoires publics ou privés. 


\title{
Discovery of Azaisoerianin Derivatives as Potential Antitumors Agents
}

\author{
Mohamed Ali Soussi, ${ }^{\mathrm{a}}$ Olivier Provot, ${ }^{\mathrm{a}}$ Guillaume Bernadat, ${ }^{\mathrm{a}}$ Jérome Bignon, ${ }^{\mathrm{b}}$ Joanna \\ Wdzieczak-Bakala, ${ }^{\mathrm{b}}$ Déborah Desravines, ${ }^{\mathrm{b}}$ Joëlle Dubois, ${ }^{\mathrm{b}}$ Jean-Daniel Brion ${ }^{\mathrm{a}}$, Samir \\ Messaoudi, ${ }^{* a}$ Mouad Alami*a \\ ${ }^{a}$ Univ Paris-Sud, CNRS, BioCIS-UMR 8076, Laboratoire de Chimie Thérapeutique, LabEx LERMIT, Equipe Labellisée Ligue \\ Contre le Cancer, Faculté de Pharmacie, 5 rue J.-B. Clément, Châtenay-Malabry, F-92296, France \\ ${ }^{b}$ Institut de Chimie des Substances Naturelles, UPR 2301, CNRS avenue de la terrasse, F-91198 Gif sur Yvette, France \\ * Corresponding authors. Tel.: +33 1468358 47. Fax: +33 1468358 28. Email: samir.messaoudi@u-psud.fr (S.M.) or \\ mouad.alami@u-psud.fr (M.A.)
}

\begin{abstract}
A series of $N$-methyl-diarylamines 2 was designed and synthesized as a novel class of CA-4 and isoCA-4 analogues. Compounds $\mathbf{2 b}$ and $\mathbf{2 m}$ showed excellent antiproliferative activity with mean $\mathrm{GI}_{50}$ values at a nanomolar level in a diverse set of human cancer cell lines. These compounds also inhibited tubulin assembly at a micromolar range, arrested the cellular cycle in the G2/M phase and induced apoptosis at very low concentrations. Preliminary in vitro results revealed that $\mathbf{2 b}$ and $\mathbf{2 m}$ displayed substancial efficacy as potent antivascular agents. Docking studies indicates that these lead compounds showed a binding mode similar to those observed with isoCA-4 at the colchicine binding site of tubulin.
\end{abstract}

Keywords: combretastatin A-4, isoCA-4, isoerianin, azaisoCA-4, cytotoxicity, antimitotic, tubulin. 


\section{Introduction}

Combretastatin A-4 (CA-4) a natural stilbene isolated from the African willow tree, Combretum caffrum in 1989 by Pettit[1] has been found to be a potent anticancer agent which strongly inhibits tubulin assembly by binding to the colchicine site.[2] CA-4 also shows potent cytotoxicity against a wide range of human cancer cell lines including multi drugs resistant (MDR) cancer cells.[3] Moreover, CA-4 has been demonstrated to selectively target the vascular network of tumors, inducing irreversible shutdown of blood flow to neoplastic cells. [4] Currently, two water-soluble prodrug derivatives are in clinical trials: disodium phosphate CA-4P (fosbretabulin, Zybrestat ${ }^{\mathrm{TM}}$ )[5] and AVE8062 (ombrabulin).[6] To date, CA-4P[7,8] either as a single agent or in combination therapy is undergoing several advanced clinical trials worldwide for the treatment of age-related macular degeneration or anaplastic thyroid cancer.

Figure 1. Structures of CA-4 and synthetic prodrugs, isoCA-4 and derivatives, erianin, isoerianin and targeted azaisoerianin.
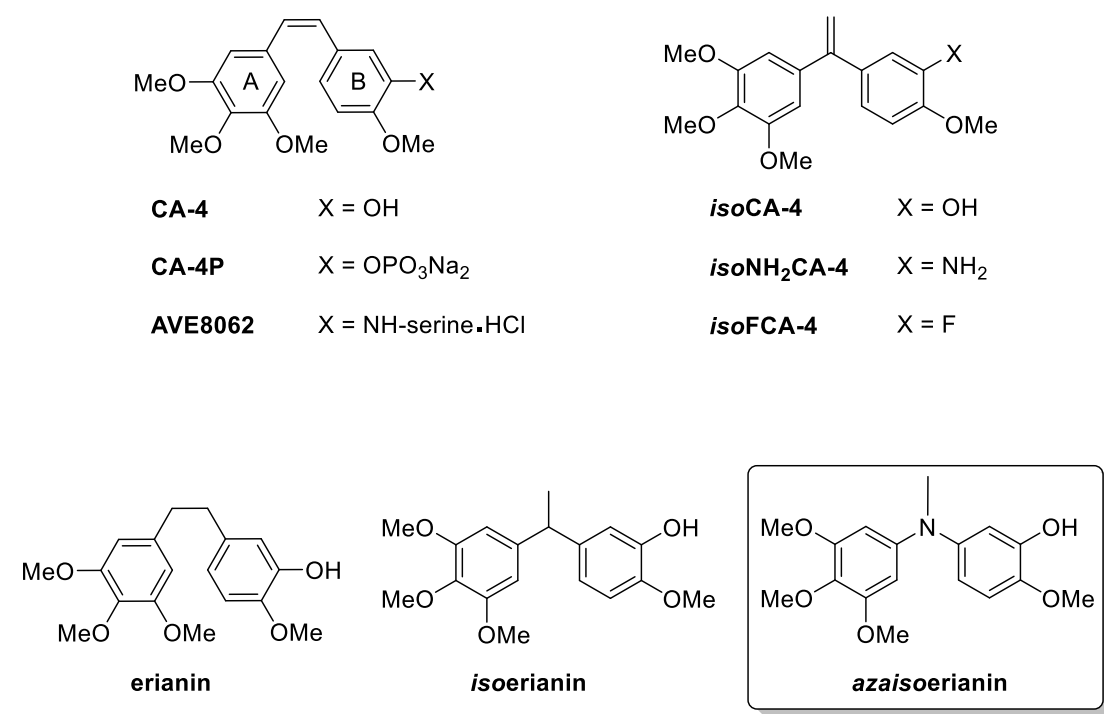

Despite their remarkable anticancer properties, the main problem associated with CA-4 and its prodrugs is the ready isomerization of the $Z$-double bond into the inactive $E$-form during storage, administration and metabolism.[9,10] In an ongoing project aimed at developing stable CA-4 analogues[11, 12, 13, 14, 15, 16, 17, 18, 19], we recently solved the stability problem of CA-4 by the discovery of the non-isomerizable isocombretastatin A-4 (isoCA-4) which holds biological activities comparable to that of CA-4.[20, 21]. This structural isomer of the natural product, having a 1,1diarylethylene scaffold, is chemically and metabolically stable [22] and easy to synthesize [23, 24, 25] at a multigrams scale without the need to control the olefin geometry. By chemical modifications on the B-ring of isoCA-4, we have also identified other stable and promising antiproliferative agents $[21,26]$ such as iso $\mathrm{NH}_{2} \mathrm{CA}-4$ and isoFCA-4. We next have demonstrated that the reduction of the 1,1-ethylene bond of isoCA-4 led to ( \pm )-isoerianin, in which racemic and both enantiomers displayed excellent anti-cancer activities comparable to that of the natural isomer erianin.[27] It seems that the carbon $\left(\mathrm{Csp}^{3}\right)$ linker in isoerianin is not involved in the interaction in the colchicine binding site. It serves only to position correctly the two aromatic rings of the molecule [27]. Herein, we planned to prepare a new class of isoerianin derivatives, named azaisoerianins (Figure 1), in which the two aromatic rings are connected through a nitrogen atom in place of the carbon linker in isoerianin compounds. Indeed, the diphenylamine skeleton is a common privileged structure found in biologically active compounds, and compounds derived from this scaffold manifest diverse activities, including anticancer activity.[28, 29] This design has several advantages as follow: $(i)$ the ease in synthesis where various side-arms can be introduced on nitrogen atom in a convergent access, (ii) the absence of a chiral center, 
(iii) the rapid access to weakly basic and chargeable derivatives in a solubilization strategy, (iv) the discovery of a third generation of candidates having promising antiproliferative and antitubulin activities and a better understanding of structure-activity relationships (SAR). In this article are described the synthesis and the biological evaluation of novel azaisoerianin derivatives $\mathbf{2}$ and 3. Preliminary in vitro efficacy of these compounds in terms of cytotoxicity, inhibition of tubulin assembly, cell cycle, apoptosis and in vitro antivascular activity is described. The possible binding mode of the most bioactive substrates $\mathbf{2} \mathbf{b}$ and $\mathbf{2} \mathbf{m}$ on tubulin is also reported.

\section{Results and discussion}

\subsection{Chemistry.}

Scheme 1. Synthesis of compounds 1-3.
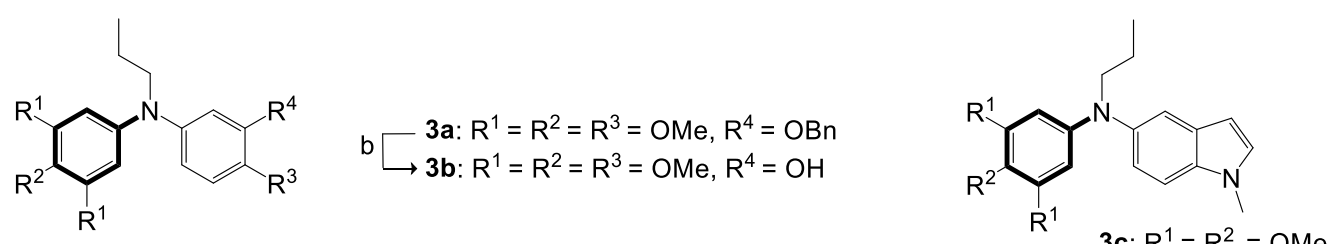<smiles>[R]c1ccc(Nc2cc([R])c([R])c([R])c2)cc1[R]</smiles>

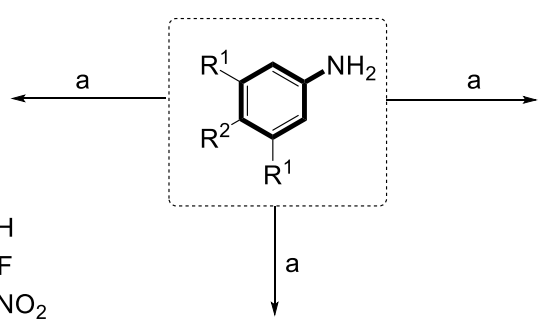

1a: $R^{1}=R^{2}=R^{3}=$ OMe, $R^{4}=H$

1b: $R^{1}=R^{2}=R^{3}=$ OMe, $R^{4}=F$

1c: $R^{1}=R^{2}=R^{3}=O M e, R^{4}=N_{2}$

1d: $R^{1}=R^{2}=O M e, R^{3}-R^{4}=(C H)_{4}$

1e: $R^{1}=R^{2}=R^{3}=O M e, R^{4}=O B n$

1f: $R^{1}=R^{2}=O M e, R^{3}=C l, R^{4}=H$
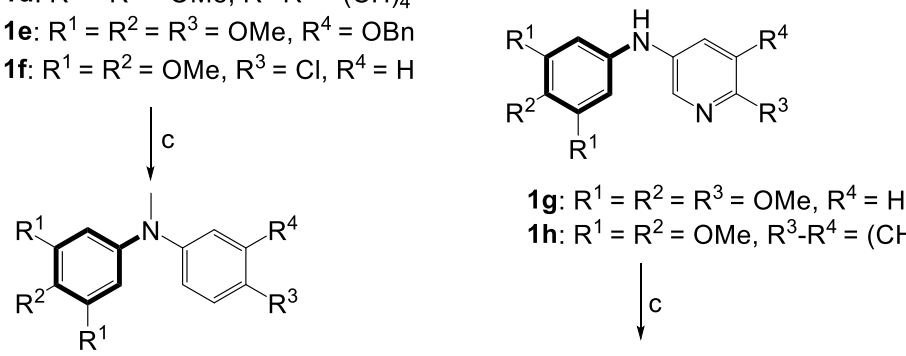

$\mathrm{R}^{1}$

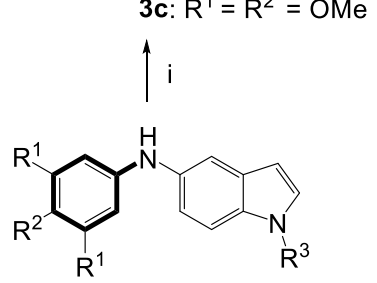

$$
\begin{aligned}
& \text { 1i: } R^{1}=R^{2}=O M e, R^{3}=M e \\
& \text { 1j: } R^{1}=H, R^{2}=O M e, R^{3}=M e \\
& \text { 1k: } R^{1}=O M e, R^{2}=H, R^{3}=M e \\
& \text { 1I: } R^{1}=R^{2}=O M e, R^{3}=S_{2} P h
\end{aligned}
$$

2a: $R^{1}=R^{2}=R^{3}=O M e, R^{4}=H$ 2b: $R^{1}=R^{2}=R^{3}=$ OMe, $R^{4}=F$

$\mathrm{d} \longrightarrow$ 2b. $\mathrm{HCl}: \mathrm{R}^{1}=\mathrm{R}^{2}=\mathrm{R}^{3}=\mathrm{OMe}, \mathrm{R}^{4}=\mathrm{F}$

2c: $R^{1}=R^{2}=R^{3}=$ OMe, $R^{4}=N_{2}$

e $\longrightarrow$ 2d: $R^{1}=R^{2}=R^{3}=O M e, R^{4}=N_{2}$

2e: $R^{1}=R^{2}=O M e, R^{3}-R^{4}=(C H)_{4}$

b- 2f: $R^{1}=R^{2}=R^{3}=O M e, R^{4}=O B n$

1g: $R^{1}=R^{2}=R^{3}=O M e, R^{4}=H$

1h: $R^{1}=R^{2}=O M e, R^{3}-R^{4}=(C H)_{4}$

$\downarrow c$

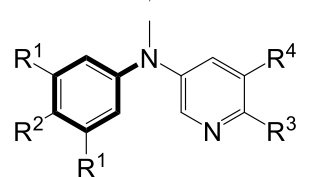

$\mathrm{R}^{1}$

2k: $\mathrm{R}^{1}=\mathrm{R}^{2}=\mathrm{R}^{3}=\mathrm{OMe}, \mathrm{R}^{4}=\mathrm{H}$ 2I: $R^{1}=R^{2}=O M e, R^{3}-R^{4}=(C H)_{4}$

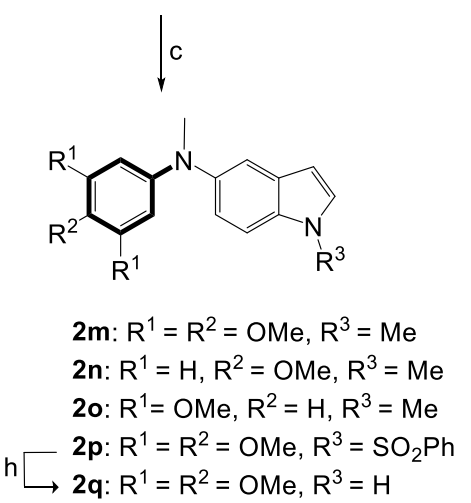

$\mathrm{h} \longrightarrow$ 2q: $\mathrm{R}^{1}=\mathrm{R}^{2}=\mathrm{OMe}, \mathrm{R}^{3}=\mathrm{H}$

2g: $R^{1}=R^{2}=R^{3}=O M e, R^{4}=O H$

$\mathrm{f} \longrightarrow 2 \mathrm{~h}: \mathrm{R}^{1}=\mathrm{R}^{2}=\mathrm{R}^{3}=\mathrm{OMe}, \mathrm{R}^{4}=\mathrm{OAC}$

2i: $R^{1}=R^{2}=$ OMe, $R^{3}=\mathrm{Cl}, R^{4}=H$

$\mathrm{g} \longrightarrow 2 \mathrm{j}: \mathrm{R}^{1}=\mathrm{R}^{2}=\mathrm{OMe}, \mathrm{R}^{3}=\mathrm{NMe}_{2} \mathrm{R}^{4}=\mathrm{H}$

${ }^{a}$ Reagents and conditions: (a) $\mathrm{Pd}(\mathrm{OAc})_{2}$, Xantphos, $\mathrm{ArX}, \mathrm{Cs}_{2} \mathrm{CO}_{3}$, dioxane, $100-130{ }^{\circ} \mathrm{C}$, sealed tube. (b) $\mathrm{H}_{2}, \mathrm{Pd} / \mathrm{C}$, AcOEt. (c) NaH, MeI, DMF, RT. (d) $\mathrm{HCl}, \mathrm{MeOH}, \mathrm{Et}_{2} \mathrm{O}$, RT. (e) $\mathrm{Fe}, \mathrm{HCl}$, EtOH/ $\mathrm{H}_{2} \mathrm{O}$. (f) Pyridine, DMAP, $(\mathrm{Ac})_{2} \mathrm{O}, \mathrm{CH}_{2} \mathrm{Cl}_{2}$. (g) $\mathrm{Pd}_{2}\left(\mathrm{dba}_{3} \mathrm{CHCl}_{3}, t-\mathrm{Bu}_{2} \mathrm{P}(o\right.$-biphenyl), $\mathrm{NHMe} 2, t \mathrm{BuONa}$, toluene, $100{ }^{\circ} \mathrm{C}$. (h) TBAF, DMF, $100{ }^{\circ} \mathrm{C}$. (i) $\mathrm{NaH}, n \operatorname{PrBr}$, DMF, RT.

The synthesis of azaisoerianin derivatives 2a-q and 3a-c, is summarized in Scheme 1. Diarylanilines 1a-l were prepared from commercially available methoxylated anilines which were coupled in a sealed tube with a variety of aryl and heteroaryl halides under our previously reported conditions $\left(\mathrm{Pd}(\mathrm{OAc})_{2}\right.$ as the catalyst, $\mathrm{Xantphos}$ as the ligand, $\mathrm{Cs}_{2} \mathrm{CO}_{3}$ as the base in hot dioxane).[30, 31, 32, 33] Treatment of the resulting diarylamines 1 with sodium hydride followed by reaction with $\mathrm{MeI}$ gave the best results for the $\mathrm{N}$-alkylation process furnishing the desired trisubstituted amines $\mathbf{2}$. By analogy with highly cytotoxic $N$-propylbenzylanilines,[34] $N$-propyl derivatives $\mathbf{3}$ were prepared using a large excess of 
$n \mathrm{PrBr}$ as the alkylating agent and $\mathrm{NaH}$ as the base. Reduction of the nitro group of $\mathbf{2 c}$ using $\mathrm{HCl}$ and iron powder yielded azasoerianin derivative 2d with 3-amino-4-methoxy groups on the B-ring similar to the B-ring of AVE8062 drug. Debenzylation of the phenol function of $\mathbf{2 f}$ was carried out by hydrogenation to afford azaisoerianin $\mathbf{2 g}$ having the greatest resemblance with isoerianin and isoCA-4. Compound $\mathbf{2 j}$ was synthesized from 4-chloro derivative $2 \mathbf{i}$ using dimethylamine in the presence of $\mathrm{Pd}_{2}(\mathrm{dba})_{3} \cdot \mathrm{CHCl}_{3}(5 \mathrm{~mol} \%)$, and Johnphos $(10 \mathrm{~mol} \%)$ as the ligand and $t \mathrm{BuONa}$ as the base in hot toluene.[35] Finally, the removal of the $N$-protected tosyl group of $\mathbf{2 p}$ was accomplished by the use of TBAF in DMF at $100{ }^{\circ} \mathrm{C}$ to afford $\mathbf{2 q}(49 \%)$.

\subsection{Biological results.}

New synthesized azaisoerianin compounds were evaluated for their cytotoxic effects against HCT116 human carcinoma cell line and for tubulin polymerization inhibitory activity. Isoerianin [27], isoCA-4 [21] and CA-4 [36] were included as reference compounds. The cytotoxicity and inhibition of tubulin polymerization (ITP) results are presented in Table

1. Without any exception, all secondary diarylamines $\mathbf{1}$ were not cytotoxic (data not shown).

Table 1 Cytotoxicity against HCT 116 cells $^{\mathrm{a}}$ and ITP of selected compounds $\mathbf{2}$ and $\mathbf{3}$

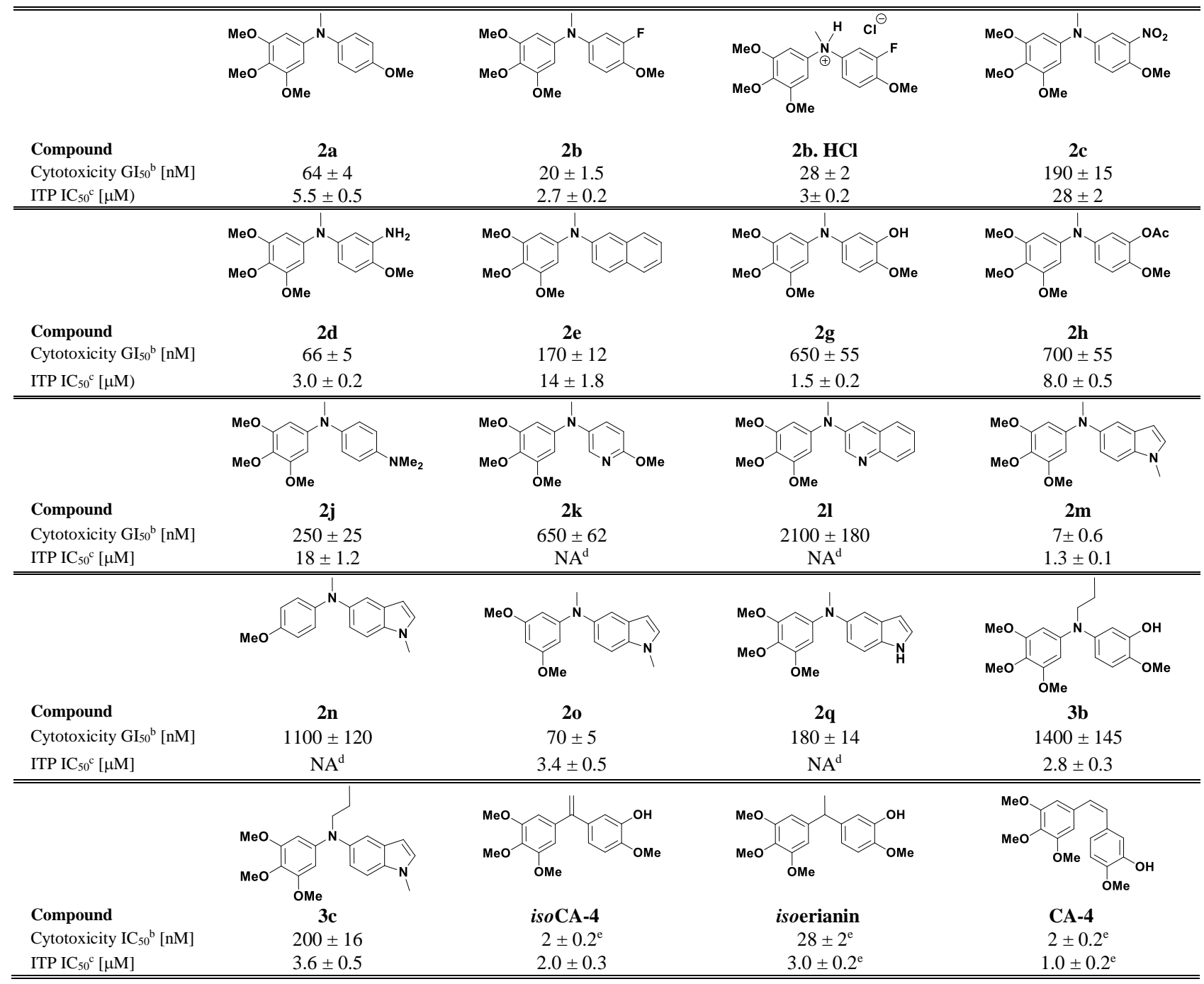

${ }^{a} \mathrm{HCT} 116$ Human colon carcinoma. ${ }^{b} \mathrm{GI}_{50}$ is the concentration of compound needed to reduce cell growth by $50 \%$ following $72 \mathrm{~h}$ cell treatment with the tested drug (average of three experiments). ${ }^{c} \mathrm{IC}_{50}$ is the concentration of compound required to inhibit $50 \%$ of the rate of microtubule assembly (average of three experiments). ${ }^{d}$ NA not active. ${ }^{e}$ The $\mathrm{GI}_{50}$ values for $i$ soCA-4, isoerianin and CA-4 were determined in this study.

In the series of compounds $\mathbf{2}$ having a benzene substituted B-ring, our findings showed that compound $\mathbf{2 b}$, having a fluorine atom at the $\mathrm{C} 3$ '-position, displayed the best cytotoxicity with a $\mathrm{GI}_{50}$ values of $20 \mathrm{nM}$ comparable to that of the reference isoerianin. Additionally, the water-soluble hydrochloride salt $\mathbf{2 b}-\mathrm{HCl}$ displayed a high level of cytotoxicity 
against HCT116 cells $\left(\mathrm{GI}_{50}=28 \mathrm{nM}\right)$ comparable to that of the parent molecule $2 \mathbf{b}\left(\mathrm{GI}_{50}=22 \mathrm{nM}\right)$. Replacement of the $\mathrm{F}$ atom with $\mathrm{H}$ or a $\mathrm{NH}_{2}$ on the C3'-position generated compounds $\mathbf{2 a}$ and $\mathbf{2 d}\left(\mathrm{GI}_{50}=64 \mathrm{nM}\right.$ and $66 \mathrm{nM}$, respectively) which were three fold less active than $\mathbf{2 b}$. Contrary to our expectations, a dramatic loss of antiproliferative activity was observed with azaisoerianin $\mathbf{2 g}$, having a $\mathrm{OH}$ group on $\mathrm{C} 3$ '-position.This compound and its corresponding acetate $\mathbf{2 h}$ displayed only modest cytotoxicity against HCT116 cells $\left(\mathrm{GI}_{50}=650-700 \mathrm{nM}\right)$. We next showed that the introduction of a pyridine or a quinoline nucleus as B-ring resulted in products $2 \mathbf{k}\left(\mathrm{GI}_{50}=650 \mathrm{nM}\right)$ and $2 \mathbf{2}\left(\mathrm{GI}_{50}=2100 \mathrm{nM}\right)$, respectively, with a significant loss of potency. We next investigated the role on cytotoxicity of derivatives having an indole nucleus which was found useful as B-ring in the CA-4 series.[37] It is significant to note that in the azaisoerianin series, $N$-methyl-indol-5-yl compound $\mathbf{2 m}$ was consistently the more potent compound. This lead compound (2m) was about four times more cytotoxic than the reference isoerianin with a low $\mathrm{GI}_{50}$ value of $7 \mathrm{nM}$. The absence of the trimethoxyphenyl-ring in the 5-indoyl series reduced the cytotoxicity as it was observed with compounds $2 \mathbf{n}\left(\mathrm{GI}_{50}=\right.$ $1100 \mathrm{nM})$ and $20\left(\mathrm{GI}_{50}=70 \mathrm{nM}\right)$. Contrary to other observations, [377] the $N$-methyl substitution of the indole moiety in $\mathbf{2 m}$ plays an important role for the antiproliferative activity. Indeed, its des-methyl analogue $\mathbf{2 q}$ showed a 25 -fold reduction in cytotoxicity. Finally, a marked loss in cytotoxicity was observed with compounds $\mathbf{3 b}\left(\mathrm{GI}_{50}=1400 \mathrm{nM}\right)$ and 3c $\left(\mathrm{GI}_{50}=200 \mathrm{nM}\right)$ having a $N$-propyl group in comparison with their $N$-methyl analogues (e.g. 3c vs $\mathbf{2 m}$; 3b vs $\mathbf{2 g}$ ). To further characterize the cytotoxicity profiles of these compounds, we next investigated the effect of the most active substances $\mathbf{2 a}, \mathbf{2 b}, \mathbf{2 d}$ and $\mathbf{2 m}$ on the proliferation of three tumor cell lines (hormone-independent breast cancer (MDAMB231), human glioblastoma (U87-MG), myelogenous leukemia (K562) and on the normal primary human umbilical vein endothelial (HUVEC). As shown in Table 2, all examined compounds displayed very potent activity against all cell lines tested, in the nanomolar range. Again, compound $\mathbf{2} \mathbf{b}$ and indole $\mathbf{2} \mathbf{m}$ displayed the highest level of cytotoxicity with $\mathrm{GI}_{50}$ values ranging from 2 to $39 \mathrm{nM}$.

Table 2. Cytotoxicity against human cancer cell lines, HCT116, MDA-MB231, U87-MG, K562 and HUVEC.

\begin{tabular}{|c|c|c|c|c|c|}
\hline \multicolumn{6}{|c|}{ Cytotoxicity $\left(\mathrm{GI}_{50} \mathrm{nM}\right)^{a}$} \\
\hline Compounds & HCT116 ${ }^{b}$ & MDA-MB231 & U87-MG & $\mathrm{K} 562^{e}$ & HUVEC $^{f}$ \\
\hline $2 \mathbf{a}$ & $64 \pm 4$ & $55 \pm 4$ & $30 \pm 2$ & $39 \pm 4$ & $35 \pm 3$ \\
\hline $2 \mathbf{b}$ & $20 \pm 1.5$ & $24 \pm 2$ & $7 \pm 0.6$ & $39 \pm 5$ & $22 \pm 2$ \\
\hline 2d & $66 \pm 5$ & $80 \pm 7$ & $20 \pm 1.7$ & $62 \pm 5$ & $25 \pm 3$ \\
\hline $2 \mathrm{~m}$ & $7 \pm 0.6$ & $16 \pm 1.8$ & $2.2 \pm 0.3$ & $8 \pm 0.7$ & $7 \pm 0.5$ \\
\hline Isoerianing ${ }^{\mathrm{g}}$ & $28 \pm 2$ & $35 \pm 3$ & $30 \pm 3$ & $25 \pm 2$ & $45 \pm 5$ \\
\hline
\end{tabular}

\footnotetext{
${ }^{a} \mathrm{GI}_{50}$ is the concentration of compound needed to reduce cell growth by $50 \%$ following $72 \mathrm{~h}$ cell treatment with the tested drug (average of three experiments). ${ }^{b}$ HCT116, colon carcinoma. ${ }^{c}$ MDA-MB-231 hormone-independent breast cancer. ${ }^{d}$ U87-MG Glioblastoma. ${ }^{e}$ K562, myelogenous leukaemia. ${ }^{f}$ HUVEC, Human umbilical vein endothelial cells. ${ }^{g}$ The $\mathrm{GI}_{50}$ values of isoerianin was determined in this study.
}

To investigate whether compounds $\mathbf{2}$ and $\mathbf{3}$ exert their activities by interacting with microtubules, their effect on the in vitro polymerization of purified tubulin was next examined (see Table 1). It is of interest to note that highly cytotoxic derivatives $\mathbf{2 b}$ and $\mathrm{N}$-methylindole $\mathbf{2} \mathbf{m}$ were also very potent as tubulin inhibitors and were comparable to isoerianin with $\mathrm{IC}_{50}$ micromolar values $(2.7 \mu \mathrm{M}$ and $1.3 \mu \mathrm{M}$ for $\mathbf{2 b}$ and $\mathbf{2 m}$, respectively). Interestingly, derivative $\mathbf{2 g}$, having the greatest resemblance to isoCA-4 and isoerianin which was poorly cytotoxicity against HCT116 cells was one of the more potent agent as tubulin inhibitor with an $\mathrm{IC}_{50}$ value of $1.5 \mu \mathrm{M}$. Similarly, $N$-propyl derivatives $\mathbf{3 b}$ and $\mathbf{3 c}$ which displayed a modest level of cytotoxicity were very potent in the tubulin assay with $\mathrm{IC}_{50}$ values ranging from 2.8 to 3.6 $\mu \mathrm{M}$. These results showed an important discrepancy between the potency of antitubulin activity and cytotoxicity of $N$ - 
propyl derivatives $\mathbf{3}$, indicating that with hindered substituents on the nitrogen atom of derivatives $\mathbf{3}$, it might be possible to design news series of antivascular agents with low cytoxicity.

To gain further insight the mechanism of action of azaisoerianin derivatives $\mathbf{2}$, the most cytotoxic compounds $\mathbf{2 b}$ and $\mathbf{2 m}$ were assayed for their effects on cell cycle distribution. K562 and HCT116 cells were treated with $\mathbf{2 b}$ and $\mathbf{2 m}$ at different concentrations for $24 \mathrm{~h}$. The results presented in Figure 2, demonstrate that there was an accumulation of K562 and HCT116 cells in the $\mathrm{G}_{2} / \mathbf{M}$ phase of the cellular cycle after treatment with $\mathbf{2} \mathbf{b}$ and $\mathbf{2} \mathbf{m}$ at very low concentrations. One note that there is a better perturbation of cycle cell progression in K562 cells after treatment with these drugs, and indolic derivative $\mathbf{2 m}$ seems to be slightly more effective than $\mathbf{2 b}$ in K562 and HCT116 cells.

Figure 2. Effects of $\mathbf{2 b}$ and $\mathbf{2 m}$ on cell cycle distribution in HCT116 and K562 cells determined by flow cytometry analysis. DNA content was assessed via propidium iodide staining.

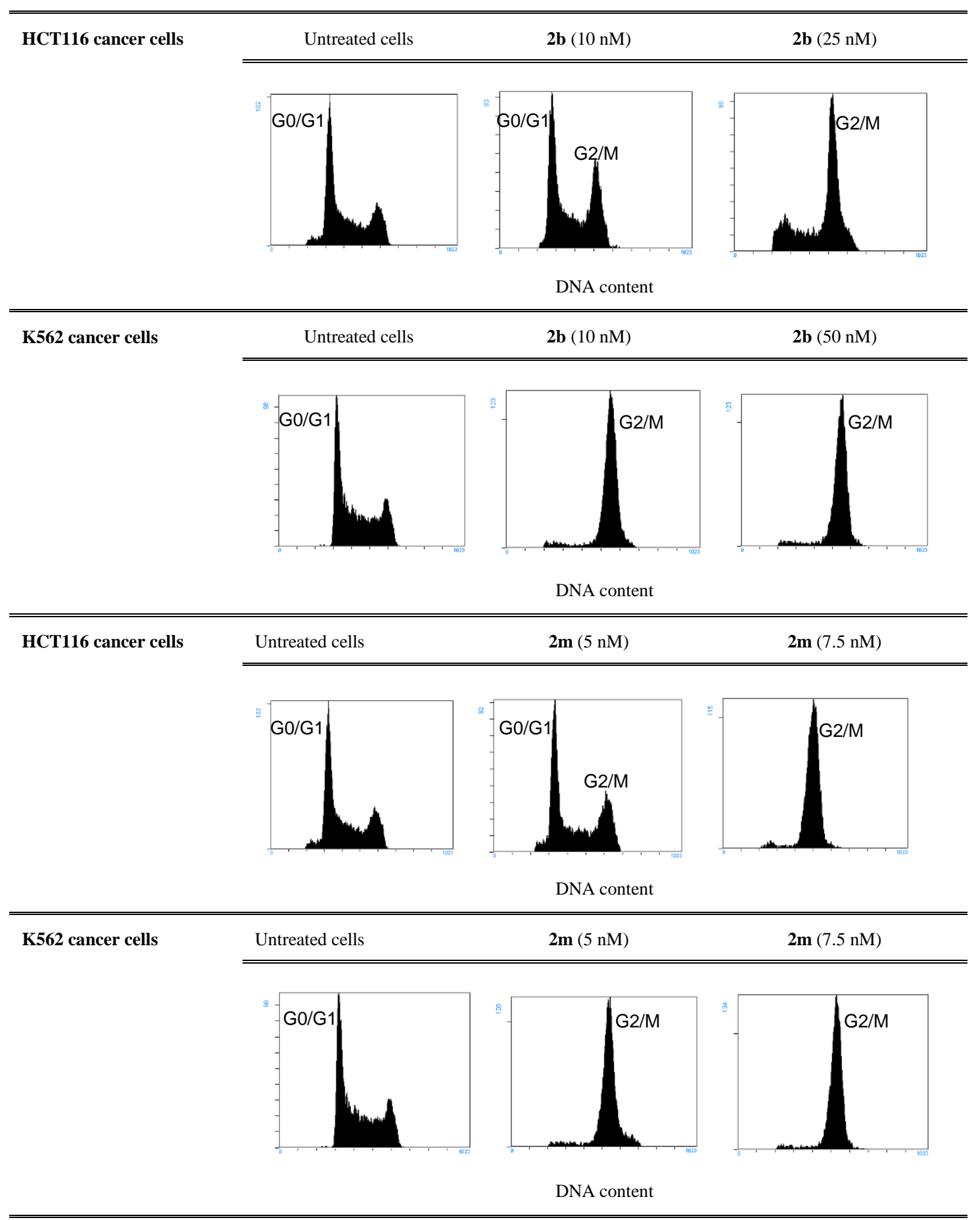


The ability of $\mathbf{2 b}$ and $\mathbf{2 m}$ to induce apoptosis in HCT116 cells was further characterized using caspase-3 and caspase-7 assays. The enzymatic activity of these caspases was measured by monitoring the cleavage of the fluorogenic substrate Z-DEVD-R110 in cancer cells. The results presented in Table 3 show a significant dose-dependent increase in proteolytic activity of caspases in the cells treated for $24 \mathrm{~h}$ with diarylmethylamines $\mathbf{2 b}$ and $\mathbf{2 m}$. A spectacular 4 -fold increase in apoptosis was evidenced by $\mathbf{2 m}$ in HCT116 cells at a low concentration of $7.5 \mathrm{nM}$. These results indicate that, in addition to their antiproliferative and antitubulin effects, the treatment of cancer cells with $\mathbf{2 b}$ and $\mathbf{2 m}$ activate caspases system leading to programmed cell death.

Table 3. Apoptotic effects of $\mathbf{2 b}$ and $\mathbf{2} \mathbf{m}$ in HCT116 cells.

\begin{tabular}{|c|c|c|c|}
\hline Rhodamine & Relative Fl & escence Int & $\%$ of cont \\
\hline $\begin{array}{c}\text { 2b } 25 \mathrm{nM} \\
(300)\end{array}$ & $\begin{array}{c}\text { 2b } 50 \mathrm{nM} \\
(452)\end{array}$ & $\begin{array}{c}\mathbf{2 m} 7.5 \mathrm{nM} \\
(393)\end{array}$ & $\begin{array}{c}\mathbf{2 m} 15 \mathrm{nM} \\
(471)\end{array}$ \\
\hline
\end{tabular}

$\overline{\bar{a}}$ The results are expressed in the percentage of apoptotic cells detected following $24 \mathrm{~h}$ of treatment with $\mathbf{2 b}$ and $\mathbf{2} \mathbf{m}$ at different concentrations.

To identify compounds that disrupt the neovascularization formation, an assay using endothelial colony-forming cells (ECFCs) was performed with a panel of diarylamines $\mathbf{2}$ and 3. In the presence of the vascular endothelial growth factor (VEGF), ECFCs form tube-like structures that express the endothelial marker (CD31) when co-cultured on an ADSC feeder layer. [38] The inhibition of endothelial tube formation $\left(\mathrm{IC}_{50}\right)$ was determined after $96 \mathrm{~h}$ of treatment using ECFCs, VEGF and compounds $\mathbf{2} \mathbf{a}-\mathbf{b}, \mathbf{2} \mathbf{d}$ and $\mathbf{2} \mathbf{m}$ as angiogenesis inhibitors.

Table 4. Inhibition of endothelial tube formation using ECFCs.

\begin{tabular}{|c|c|c|c|c|c|c|c|c|c|c|c|c|c|}
\hline & \multicolumn{13}{|c|}{ Inhibition of endothelial colony tube formation } \\
\hline $\begin{array}{c}\text { Compounds } \\
\left(\mathrm{IC}_{50}\right) \mathrm{nM}\end{array}$ & $\begin{array}{l}\mathbf{2 a} \\
56\end{array}$ & $\begin{array}{l}\mathbf{2 b} \\
25\end{array}$ & $\begin{array}{c}\mathbf{2 c} \\
300\end{array}$ & $\begin{array}{c}\mathbf{2 k} \\
2000\end{array}$ & $\begin{array}{c}\mathbf{2 l} \\
\mathrm{NA}^{a}\end{array}$ & $\begin{array}{c}2 \mathrm{~m} \\
8\end{array}$ & $\begin{array}{c}\mathbf{2 n} \\
\mathrm{NA}^{a}\end{array}$ & $\begin{array}{l}20 \\
67\end{array}$ & $\begin{array}{c}\mathbf{2 q} \\
250\end{array}$ & $\begin{array}{l}\mathbf{3 b} \\
73\end{array}$ & $\begin{array}{l}3 c \\
50\end{array}$ & $\begin{array}{c}\text { isoerianin } \\
70\end{array}$ & $\begin{array}{c}\text { isoCA-4 } \\
7\end{array}$ \\
\hline
\end{tabular}

${ }^{a}$ Not Active

Compounds $\mathbf{2 k}, \mathbf{2 l}$ having a pyridine and quinoline B-rings respectively, as well as $\mathbf{2 n}$ were found to be inactive as angiogenesis inhibitors (Table 4). All other selected compounds inhibit the endothelial tube formation in a concentration-dependent manner (data not shown) with remarkable low $\mathrm{IC}_{50}$ values as for examples with $\mathbf{2 b}$ or $\mathbf{2 m}\left(\mathrm{CI}_{50}\right.$ $=25$ and $8 \mathrm{nM}$, respectively). One can note that $N$-propyl derivatives $\mathbf{3 b}$ and $\mathbf{3 c}$ which displayed a low level of cytotoxicity (Table 1) inhibit angiogenesis with nanomolar $\mathrm{IC}_{50}$ values of 73 and $50 \mathrm{nM}$, respectively.

Figure 3.

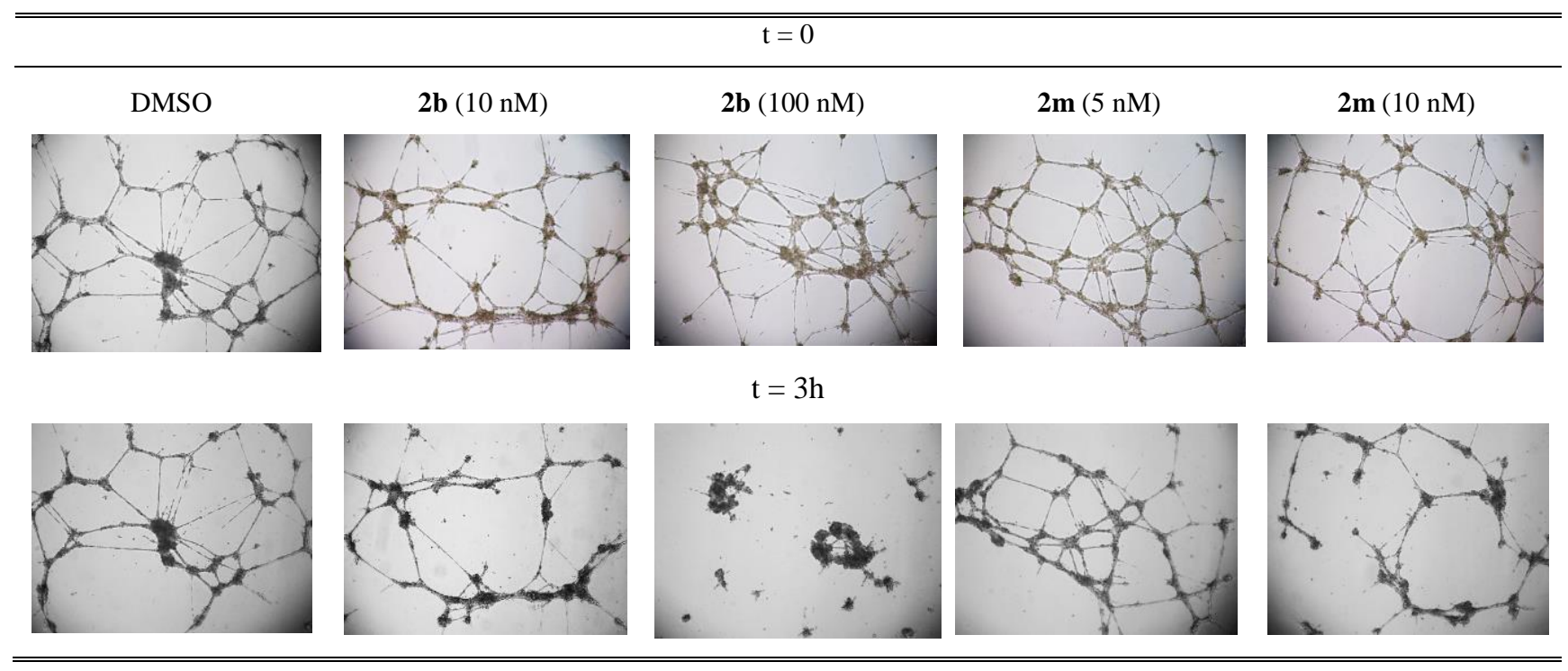


These results were next confirmed by a second in vitro model of angiogenesis [39] in which human umbilical vein endothelial cells (HUVECs), when seeded on Matrigel $^{\mathrm{TM}}$, aggregate to form a reticular vascular network of capillarylike vessels. The results presented in Table 2 (see above) revealed that after $72 \mathrm{~h}$ of incubation, $\mathbf{2 b}$ and $\mathbf{2 m}$ exhibited good growth inhibition activity against HUVEC cells with $\mathrm{GI}_{50}$ values of 22 and $7 \mathrm{nM}$, respectively. To evaluate whether $\mathbf{2 b}$ and $\mathbf{2} \mathbf{m}$ could affect models of newly formed blood vessels, the HUVEC tube disruption assay was performed. Addition of $\mathbf{2 b}$ at a concentration of $10 \mathrm{nM}$, and more significantly at $100 \mathrm{nM}$, rapidly disrupted the integrity of the network (Figure 3). This effect was visible after only $3 \mathrm{~h}$ of treatment at doses of 10 and $100 \mathrm{nM}$ which were not cytotoxic for such incubation time (data not shown). This antivascular effect is even more pronounced with indole derivative $\mathbf{2 m}$ which destroyed neovascularization at a very low dose of $5 \mathrm{nM}$. All together these results suggested that azaisoserianin derivatives $\mathbf{2}$, and particularly $\mathbf{2} \mathbf{m}$ and $\mathbf{2} \mathbf{b}$, might be considered and evaluated as vascular disrupting agents for further in vivo studies.

\subsection{Docking study.}

The biological IPT and antivascular results demonstrated that tubulin is the target of these diarylamines 2 and 3 . Molecular docking calculations were performed with $\mathbf{2 b}$ and $\mathbf{2} \mathbf{m}$ in order to investigate their possible binding mode in the colchicine binding site of tubulin. For this purpose, the X-ray structure of tubulin DAMA-colchicine complex (accession code 1SA0) [40] was used. Figure 4 illustrates the docking-derived superimposition of $\mathbf{2 b}$ and $\mathbf{2 m}$, with isoCA-4 (green). As expected, these diarylamines showed a binding pose matching the one calculated under the same conditions for isoCA-4, used as a reference compound with its A-trimethoxyphenyl ring placed in the proximity of Cys241. Additionally, the 4'-OMe substituent of $\mathbf{2 b}$ accepts a stabilizing H-bond donated by a polar hydrogen atom belonging to the side-chain amide moiety of Asn101.

Figure 4. Calculated binding mode for $\mathbf{2 b}$ and $\mathbf{2 m}$ in the colchicine binding site of tubulin and superimposition of the latter with that of isoCA-4. (Central nitrogen atom and (if applicable) fluorine atom are represented as spheres in order to increase their visibility.)

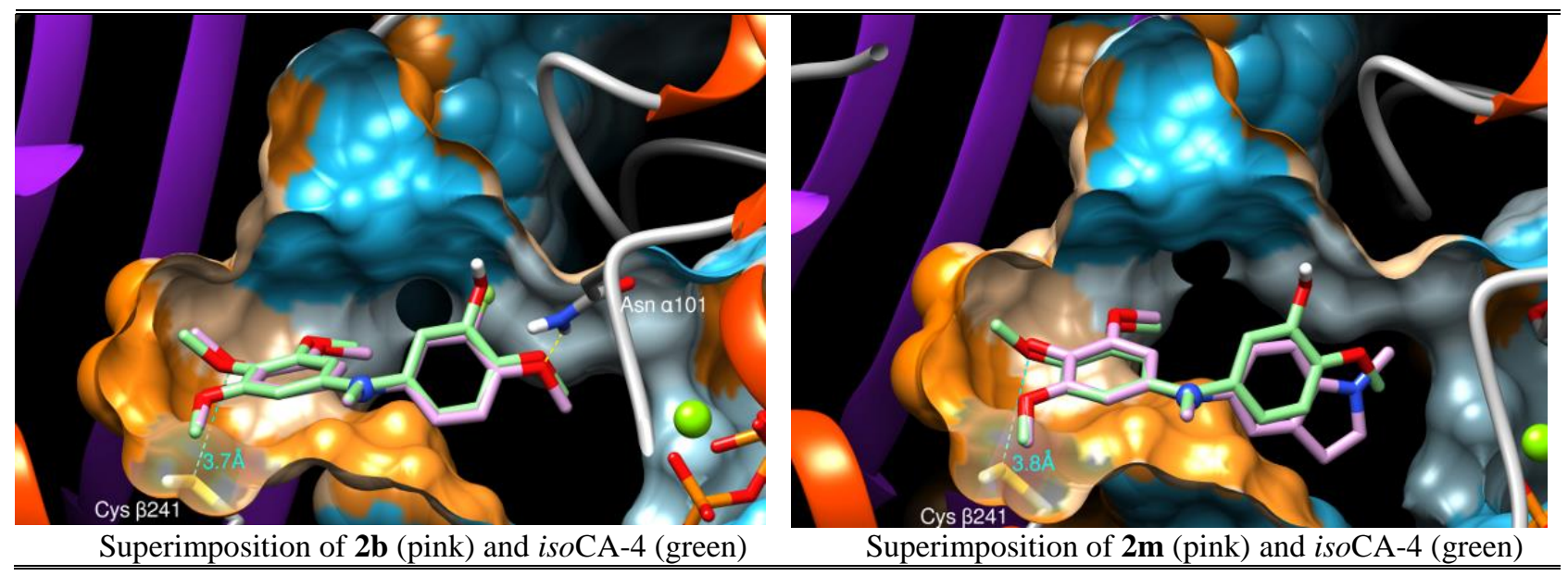

\section{Conclusions}

We designed and synthesized a series of original $N$-methyl- and $N$-propyldiarylamines $\mathbf{2}$ and $\mathbf{3}$, respectively as azaanalogues of isoerianin and isoCA-4. High inhibition of cell growth was observed with compounds $\mathbf{2 b}$ and $\mathbf{2 m}$ in a range of human cancer cells. These potent drugs also inhibited tubulin assembly with micromolar $\mathrm{IC}_{50}$ values. Cell cycle analysis of K562 and HCT116 cells treated with nanomolar concentrations of $\mathbf{2 b}$ and $\mathbf{2 m}$ indicated that cells were 
arrested at the G2/M phase. Moreover, 2b and 2m induced apoptosis in HCT116 cells and destroyed in vitro models of neovasculature at very low doses. Docking studies revealed that these compounds adopted an orientation similar to that of isoCA-4 in the colchicine binding-site of tubulin.

\section{Experimental}

\subsection{General considerations}

The compounds were all identified by usual physical methods, i.e. ${ }^{1} \mathrm{H}-\mathrm{NMR},{ }^{13} \mathrm{C}-\mathrm{NMR}$, IR, MS. ${ }^{1} \mathrm{H}$ and ${ }^{13} \mathrm{C}$ NMR spectra were measured in $\mathrm{CDCl}_{3}$ with a Bruker Avance 300. ${ }^{1} \mathrm{H}$ chemical shifts are reported in ppm from an internal standard TMS or of residual chloroform (7.27 ppm). The following abbreviations are used: m (multiplet), s (singlet), d (doublet), br s (broad singlet), $\mathrm{t}$ (triplet), dd (doublet of doublet), td (triplet of doublet). ${ }^{13} \mathrm{C}$ chemical shifts are reported in ppm from the central peak of $\mathrm{CDCl}_{3}$ (77.14). IR spectra were measured on a Bruker Vector 22 spectrophotometer $\left(\right.$ neat, $\mathrm{cm}^{-1}$ ). Mass spectra were obtained with a LCT Micromass spectrometer. Analytical TLC was performed on Merck precoated silica gel 60F plates. Merck silica gel 60 (230-400 mesh) was used for column chromatography.

\subsection{3,4,5-Trimethoxy-N-(4-methoxyphenyl)- $N$-methylaniline $\mathbf{2 a}$}

In a sealed tube and under an argon atmosphere were added successively, $\mathrm{Pd}(\mathrm{OAc})_{2}(11 \mathrm{mg} ; 5 \mathrm{~mol} \%)$, Xantphos (29 mg; 5 mol\%), 1-bromo-4-methoxybenzene (187 mg; $1 \mathrm{mmol}), 3,4,5$-trimethoxyaniline (275 mg; $1.5 \mathrm{mmol}), \mathrm{Cs}_{2} \mathrm{CO}_{3}$ $(652 \mathrm{mg} ; 2 \mathrm{mmol})$ in dioxane $(2 \mathrm{~mL})$. After heating at $100^{\circ} \mathrm{C}$ for $12 \mathrm{~h}$, the resulting suspension was cooled to room temperature and filtered through a pad of Celite eluting with ethyl acetate, and the inorganic salts were removed. The filtrate was concentrated and a rapid purification by silica gel column chromatography of the residue to eliminate the excess of 3,4,5-trimethoxyaniline gave the desired product 1a which was immediately engaged in the alkylation step. 1a: $(75 \mathrm{mg}, 26 \%) ;{ }^{1} \mathrm{H} \mathrm{NMR}\left(300 \mathrm{MHz}, \mathrm{CDCl}_{3}\right) \delta 7.04(\mathrm{~d}, 2 \mathrm{H}, J=9.0 \mathrm{~Hz}), 6.85(\mathrm{~d}, 2 \mathrm{H}, J=9.0 \mathrm{~Hz}), 6.15(\mathrm{~s}, 2 \mathrm{H}), 5.52$ (s, 1H), 3.79 (s, 6H), 3.76 (s, 3H). ${ }^{13} \mathrm{C}$ NMR (75 MHz, $\mathrm{CDCl}_{3}$ ) $\delta 155.1,153.9$ (2), 141.6, 136.1, 131.5, 121.8 (2), 114.7 (2), 93.7 (2), 61.1, 55.9 (2), 55.6. IR (neat) $v_{\max } / \mathrm{cm}^{-1}: 3278,2993,1600,1501,1224,1124,1007$. MS (APCI) $m / z: 290$ $[\mathrm{M}+\mathrm{H}]^{+}$. To a diarylamine 1a $(50 \mathrm{mg} ; 0.17 \mathrm{mmol})$ solution in $\mathrm{DMF}(2 \mathrm{~mL})$ was added at $0^{\circ} \mathrm{C}, \mathrm{NaH}(8 \mathrm{mg} ; 0.34 \mathrm{mmol})$, and iodomethane (48 mg; $28 \mu \mathrm{L}, 0.34 \mathrm{mmol}$ ). The mixture was stirred at r.t. for a night and diluted in EtOAc (2 mL) and washed with aqueous $\mathrm{NaHCO}_{3}$. The organic layer was dried, evaporated, and the residue was subjected to flash chromatography to give $\mathbf{2 a}$ as a yellow oil $(35 \mathrm{mg}, 67 \%) .{ }^{1} \mathrm{H} \mathrm{NMR}\left(300 \mathrm{MHz}, \mathrm{CDCl}_{3}\right) \delta 7.05(\mathrm{~d}, 2 \mathrm{H}, J=8.9 \mathrm{~Hz}), 6.88$ $(\mathrm{d}, 2 \mathrm{H}, J=8.9 \mathrm{~Hz}), 6.05(\mathrm{~s}, 2 \mathrm{H}), 3.81(\mathrm{~s}, 3 \mathrm{H}), 3.79(\mathrm{~s}, 3 \mathrm{H}), 3.76(\mathrm{~s}, 6 \mathrm{H}), 3.25(\mathrm{~s}, 3 \mathrm{H}) .{ }^{13} \mathrm{C} \mathrm{NMR}\left(75 \mathrm{MHz}, \mathrm{CDCl}_{3}\right) \delta$ 155.9, 153.6 (2), 146.5, 142.5, 131.6, 125.1 (2), 114.8 (2), 95.1 (2), 61.2, 56.1 (2), 55.6, 41.0. IR (neat) $v_{\text {max }} / \mathrm{cm}^{-1}: 1575$, 1503, 1465, 1419, 1242, 1127. MS (APCI) m/z: $304[\mathrm{M}+\mathrm{H}]^{+}$. HRMS calcd for $\mathrm{C}_{17} \mathrm{H}_{22} \mathrm{NO}_{4}[\mathrm{M}+\mathrm{H}]^{+} 304.1549$, obsd. 304.1548 .

\section{3.a. $N$-(3-Fluoro-4-methoxyphenyl)-3,4,5-trimethoxy-N-methylaniline $\mathbf{2 b}$}

By following the general procedure described above for 1a. Heating at $100{ }^{\circ} \mathrm{C} 3,4,5$-trimethoxyaniline $(275 \mathrm{mg} ; 1.5$ mmol) and 4-bromo-2-fluoro-1-methoxybenzene (205 mg; $1 \mathrm{mmol})$ for $5 \mathrm{~h}$ gave $1 \mathrm{~b}(181 \mathrm{mg} ; 59 \%)$. ${ }^{1} \mathrm{H} \mathrm{NMR}(300$ $\left.\mathrm{MHz} \mathrm{CDCl}_{3}\right) \delta 6.92-6.84(\mathrm{~m}, 2 \mathrm{H}), 6.76(\mathrm{~d}, 1 \mathrm{H}, J=8.7 \mathrm{~Hz}), 6.22(\mathrm{~s}, 2 \mathrm{H}), 5.45(\mathrm{~s}, 1 \mathrm{H}), 3.87(\mathrm{~s}, 3 \mathrm{H}), 3.80(\mathrm{~s}, 9 \mathrm{H}) .{ }^{13} \mathrm{C}$ NMR (75 MHz, $\left.\mathrm{CDCl}_{3}\right) \delta 154.0(2), 153.0(\mathrm{~d}, J=244.5 \mathrm{~Hz}), 142.4(\mathrm{~d}, J=11.2 \mathrm{~Hz}), 140.1,137.6(\mathrm{~d}, J=9.0 \mathrm{~Hz}), 132.7$, 115.1 (d, J=2.2 Hz), 114.5 (d, J=2.2 Hz), 107.8 (d, J=20.2 Hz), 95.4 (2), 61.1, 57.1, 56.1 (2). ${ }^{19} \mathrm{~F}$ NMR (188 MHz, $\left.\mathrm{CDCl}_{3}\right) \delta$-131.0. IR (neat) $v_{\max } / \mathrm{cm}^{-1}: 1604,1502,1464,1262,1129,1030 . \mathrm{MS}$ (APCI) $m / z: 308$ [M+H] $]^{+}$By following the general procedure described above for $\mathbf{2 a}$. Diarylamine $\mathbf{1 b}(102 \mathrm{mg} ; 0.33 \mathrm{mmol}), \mathrm{NaH}(12 \mathrm{mg} ; 0.5 \mathrm{mmol})$ and CH 3 (71 mg; $0.5 \mathrm{mmol})$ gave $\mathbf{2 b}$ as a yellow oil $(80 \mathrm{mg} ; 75 \%) .{ }^{1} \mathrm{H} \mathrm{NMR}\left(300 \mathrm{MHz}, \mathrm{CDCl}_{3}\right) \delta 6.87(\mathrm{dd}, 1 \mathrm{H}, J=9.3 \mathrm{~Hz}, J=$ 
$9.0 \mathrm{~Hz}), 6.75(\mathrm{dd}, 1 \mathrm{H}, J=13.3 \mathrm{~Hz}, J=2.7 \mathrm{~Hz}), 6.71-6.66(\mathrm{~m}, 1 \mathrm{H}), 6.18(\mathrm{~s}, 2 \mathrm{H}), 3.84(\mathrm{~s}, 3 \mathrm{H}), 3.80(\mathrm{~s}, 3 \mathrm{H}), 3.76(\mathrm{~s}, 6 \mathrm{H})$, $3.22(\mathrm{~s}, 3 \mathrm{H}) .{ }^{13} \mathrm{C}$ NMR $\left(75 \mathrm{MHz}, \mathrm{CDCl}_{3}\right) \delta 153.6(2), 152.7(\mathrm{~d}, J=243.7 \mathrm{~Hz}), 145.4,143.4(\mathrm{~d}, J=8.4 \mathrm{~Hz}), 142.3(\mathrm{~d}, J=$ $11.1 \mathrm{~Hz}), 133.2,115.9$ (d, $J=2.7 \mathrm{~Hz}), 114.6(\mathrm{~d}, J=2.3 \mathrm{~Hz}), 109.1$ (d, $J=20.5 \mathrm{~Hz}), 98.2(2), 61.0,56.9,56.1(2), 40.8$. ${ }^{19} \mathrm{~F}$ NMR $\left(188 \mathrm{MHz}, \mathrm{CDCl}_{3}\right) \delta$-133.4. IR (neat) $v_{\max } / \mathrm{cm}^{-1}: 2999,1604,1581,1503,1242,1125$. MS (APCI) $\mathrm{m} / \mathrm{z}: 322$ $[\mathrm{M}+\mathrm{H}]^{+}$. HRMS calcd for $\mathrm{C}_{17} \mathrm{H}_{21} \mathrm{FNO}_{4}[\mathrm{M}+\mathrm{H}]^{+}$322.1455, obsd. 322.1450.

\section{3.b. $N$-(3-fluoro-4-methoxyphenyl)-3,4,5-trimethoxy- $N$-methylbenzenaminium chloride $\mathbf{2 b . H C l}$}

To a solution of $\mathbf{2 b}(97 \mathrm{mg} ; 1 \mathrm{mmol})$ in $\mathrm{MeOH}-\mathrm{Et}_{2} \mathrm{O}(1: 1)(10 \mathrm{~mL})$ was added $\mathrm{HCl}_{\mathrm{g}}$ within 10 min and then the mixture was stirred for $1 \mathrm{~h}$ at RT. The precipitated salt $\mathbf{2 b . H C l}(92 \mathrm{mg} ; 86 \%)$ was isolated as green amorphous solid after filtration. ${ }^{1} \mathrm{H}$ NMR (300 MHz, DMSO) $\delta 7.06(\mathrm{t}, J=9.4 \mathrm{~Hz}, 1 \mathrm{H}), 6.83(\mathrm{dd}, J=13.8,2.5 \mathrm{~Hz}, 1 \mathrm{H}), 6.73(\mathrm{~d}, J=8.9 \mathrm{~Hz}$, 1H), $6.60(\mathrm{~s}, 1 \mathrm{H}), 6.25(\mathrm{~s}, 2 \mathrm{H}), 3.78(\mathrm{~s}, 3 \mathrm{H}), 3.69(\mathrm{~s}, 6 \mathrm{H}), 3.61(\mathrm{~s}, 3 \mathrm{H}), 3.19(\mathrm{~s}, 3 \mathrm{H}) .{ }^{13} \mathrm{C} \mathrm{NMR}(75 \mathrm{MHz}, \mathrm{DMSO}) \delta$ 153.86 (2C), 152.19 (d, $J=233.9 \mathrm{~Hz}), 145.37,143.40$ (d, $J=8.5 \mathrm{~Hz}), 141.91$ (d, $J=11.1 \mathrm{~Hz}), 133.19,116.20,115.32$, $108.60(\mathrm{~d}, J=20.2 \mathrm{~Hz}), 99.00(2 \mathrm{C}), 60.56,56.88,56.28$ (2C), 41.02. IR (neat) $v_{\max } / \mathrm{cm}^{-1}: 2999,1612,1521,1488$, 1275, 1122, 1005. MS (APCI) $m / z: 322[\mathrm{M}]^{+}$. HRMS calcd for $\mathrm{C}_{17} \mathrm{H}_{21} \mathrm{FNO}_{4}[\mathrm{M}]^{+}$322.1449, obsd. 322.1442.

\subsection{3,4,5-Trimethoxy-N-(4-methoxy-3-nitrophenyl)-N-methylaniline 2c}

By following the general procedure described above for 1a. Heating at $100^{\circ} \mathrm{C} \mathrm{3,4,5-trimethoxyaniline}(275 \mathrm{mg}$; 1.5 mmol) and 4-iodo-1-methoxy-2-nitrobenzene $(279 \mathrm{mg} ; 1 \mathrm{mmol})$ in the presence of $\mathrm{Pd}(\mathrm{OAc})_{2}(22 \mathrm{mg} ; 10 \mathrm{~mol} \%)$, Xantphos (58 mg; $10 \mathrm{~mol} \%)$ for $1 \mathrm{~h} 30$ gave $1 \mathrm{c}(307 \mathrm{mg} ; 92 \%) .{ }^{1} \mathrm{H} \mathrm{NMR}\left(300 \mathrm{MHz}, \mathrm{CDCl}_{3}\right) \delta 7.55(\mathrm{~d}, 1 \mathrm{H}, J=2.8 \mathrm{~Hz})$, $7.21(\mathrm{dd}, 1 \mathrm{H}, J=9.0 \mathrm{~Hz}, J=2.8 \mathrm{~Hz}), 7.01(\mathrm{~d}, 1 \mathrm{H}, J=9.0 \mathrm{~Hz}), 6.25(\mathrm{~s}, 2 \mathrm{H}), 5.59(\mathrm{~s}, 1 \mathrm{H}), 3.92(\mathrm{~s}, 3 \mathrm{H}), 3.81(\mathrm{~s}, 3 \mathrm{H}), 3.80$ (s, 6H). ${ }^{13} \mathrm{C}$ NMR $\left(75 \mathrm{MHz}, \mathrm{CDCl}_{3}\right) \delta 154.2(2), 147.6,140.2,139.0,137.3,133.4,124.2,115.3,114.9,96.3$ (2), 61.2, 57.2, 56.2 (2). IR (neat) $v_{\max } / \mathrm{cm}^{-1}: 1600,1535,1347,1302,1230,1122,1021 . \mathrm{MS}$ (APCI) m/z: $335[\mathrm{M}+\mathrm{H}]^{+}$.

By following the general procedure described above for 2a. Diarylamine 1c (167 mg; $0.5 \mathrm{mmol}), \mathrm{NaH}$ (18 mg; 0.75 $\mathrm{mmol})$ and $\mathrm{CH}_{3} \mathrm{I}(106 \mathrm{mg} ; 0.75 \mathrm{mmol})$ gave $2 \mathrm{c}$ as an orange oil $\left(172 \mathrm{mg}\right.$; 99\%). ${ }^{1} \mathrm{H} \mathrm{NMR}\left(300 \mathrm{MHz}, \mathrm{CDCl}_{3}\right) \delta 7.41(\mathrm{~d}$, $1 \mathrm{H}, J=2.9 \mathrm{~Hz}), 7.09(\mathrm{dd}, 1 \mathrm{H}, J=9.1 \mathrm{~Hz}, J=2.9 \mathrm{~Hz}), 6.97(\mathrm{~d}, 1 \mathrm{H}, J=9.1 \mathrm{~Hz}), 6.26(\mathrm{~s}, 2 \mathrm{H}), 3.91(\mathrm{~s}, 3 \mathrm{H}), 3.83(\mathrm{~s}, 3 \mathrm{H})$, $3.79(\mathrm{~s}, 6 \mathrm{H}), 3.27$ (s, 3H). ${ }^{13} \mathrm{C}$ NMR $\left(75 \mathrm{MHz}, \mathrm{CDCl}_{3}\right) \delta$ 154.0 (2), 146.9, 144.6, 143.0, 140.1, 134.6, 124.6, 115.0, 114.8, 100.3 (2), 61.1, 57.2, 56.2 (2), 40.9. IR (neat) $v_{\max } / \mathrm{cm}^{-1}: 1589,1525,1502,1443,1364,1254,1234,1122 . \mathrm{MS}$ (APCI) $m / z: 349[\mathrm{M}+\mathrm{H}]+$. HRMS calcd for $\mathrm{C}_{17} \mathrm{H}_{21} \mathrm{~N}_{2} \mathrm{O}_{6}[\mathrm{M}+\mathrm{H}]^{+}$349.1400, obsd. 349.1392

\subsection{4-Methoxy-N-methyl-N-(3,4,5-trimethoxyphenyl)benzene-1,3-diamine $\mathbf{2 d}$}

To a $\left(\mathrm{EtOH} / \mathrm{H}_{2} \mathrm{O}: 4 / 1\right)$ solution $(1.5 \mathrm{~mL})$ of $2 \mathrm{c}(140 \mathrm{mg}$; $0.4 \mathrm{mmol})$ were added iron $(225 \mathrm{mg} ; 4 \mathrm{mmol})$ and a drop of $\mathrm{HCl} 12 \mathrm{~N}$. After refluxing for $2 \mathrm{~h}$, the mixture was filtered through a pad of Celite, concentrated to give a residue which was subjected to flash chromatography to give $2 \mathbf{d}$ as a brown oil $(96 \mathrm{mg}, 76 \%) .{ }^{1} \mathrm{H} \mathrm{NMR}\left(300 \mathrm{MHz}, \mathrm{CDCl}_{3}\right) \delta 6.74(\mathrm{~d}$, $1 \mathrm{H}, J=8.3 \mathrm{~Hz}), 6.49-6.44(\mathrm{~m}, 2 \mathrm{H}), 6.09(\mathrm{~s}, 2 \mathrm{H}), 3.84(\mathrm{~s}, 3 \mathrm{H}), 3.79(\mathrm{~s}, 3 \mathrm{H}), 3.76(\mathrm{~s}, 6 \mathrm{H}), 3.21(\mathrm{~s}, 3 \mathrm{H}), \mathrm{NH}_{2}$ not seen. ${ }^{13} \mathrm{C}$ NMR (75 MHz, $\left.\mathrm{CDCl}_{3}\right) \delta 153.6$ (2), 146.6, 143.8, 143.2, 136.9, 131.7, 113.3, 111.3, 110.8, 95.7 (2), $61.1,56.2$ (2), 55.9, 41.0. IR (neat) $v_{\max } / \mathrm{cm}^{-1}: 1612,1581,1502,1148,1248,1126$. MS (APCI) m/z: 319 [M+H]+. HRMS calcd for $\mathrm{C}_{17} \mathrm{H}_{23} \mathrm{~N}_{2} \mathrm{O}_{4}[\mathrm{M}+\mathrm{H}]^{+}$319.1658, obsd. 319.1654.

4.6. N-Methyl-N-(3,4,5-trimethoxyphenyl)naphthalen-2-amine $\mathbf{2 e}$

By following the general procedure described above for 1a. Heating at $100^{\circ} \mathrm{C} 3,4,5$-trimethoxyaniline $(275 \mathrm{mg}$; 1.5 $\mathrm{mmol})$ and 2-iodonaphtalene $(254 \mathrm{mg} ; 1 \mathrm{mmol})$ in the presence of $\mathrm{Pd}(\mathrm{OAc})_{2}(22 \mathrm{mg} ; 10 \mathrm{~mol} \%)$, Xantphos (58 mg; 10 mol\%) for $3 \mathrm{~h}$ gave $1 \mathrm{~d}(213 \mathrm{mg} ; 69 \%) .{ }^{1} \mathrm{H} \mathrm{NMR}\left(300 \mathrm{MHz}, \mathrm{CDCl}_{3}\right) \delta 7.77(\mathrm{~d}, 2 \mathrm{H}, J=8.5 \mathrm{~Hz}), 7.67(\mathrm{~d}, 1 \mathrm{H}, J=8.2$ 
$\mathrm{Hz}), 7.46-7.42(\mathrm{~m}, 2 \mathrm{H}), 7.36-7.22(\mathrm{~m}, 2 \mathrm{H}), 6.45(\mathrm{~s}, 2 \mathrm{H}), 5.86(\mathrm{~s}, 1 \mathrm{H}), 3.89(\mathrm{~s}, 3 \mathrm{H}), 3.84(\mathrm{~s}, 6 \mathrm{H}) .{ }^{13} \mathrm{C} \mathrm{NMR}(75 \mathrm{MHz}$ $\left.\mathrm{CDCl}_{3}\right) \delta 153.9$ (2), 141.4, 139.2, 134.7, 133.2, 129.2, 129.1, 127.7, 126.5, 126.5, 123.5, 119.9, 111.5, 96.4 (2), 61.1, 56.1 (2). IR (neat) $v_{\max } / \mathrm{cm}^{-1}: 1631,1596,1503,1465,1223,1127,1006$. MS (APCI) m/z: 310 [M+H] ${ }^{+}$. By following the general procedure described above for 2a. Diarylamine 1d (155 mg; $0.5 \mathrm{mmol}), \mathrm{NaH}(18 \mathrm{mg} ; 0.75 \mathrm{mmol})$ and $\mathrm{CH}_{3} \mathrm{I}$ (106 mg; $0.75 \mathrm{mmol})$ gave $2 \mathrm{e}$ as a yellow oil $(140 \mathrm{mg} ; 87 \%) .{ }^{1} \mathrm{H} \mathrm{NMR}\left(300 \mathrm{MHz}, \mathrm{CDCl}_{3}\right) \delta 7.72(\mathrm{t}, 2 \mathrm{H}, J=7.8 \mathrm{~Hz})$, $7.66(\mathrm{~d}, 1 \mathrm{H}, J=9.0 \mathrm{~Hz}), 7.45-7.39(\mathrm{td}, 1 \mathrm{H}, J=8.6 \mathrm{~Hz}, J=1.3 \mathrm{~Hz}), 7.33-7.28(\mathrm{~m}, 1 \mathrm{H}), 7.25(\mathrm{~d}, 1 \mathrm{H}, J=2.5 \mathrm{~Hz}), 7.17$ $(\mathrm{dd}, 1 \mathrm{H}, J=8.9 \mathrm{~Hz}, J=2.4 \mathrm{~Hz}), 6.39$ (s, 2H), 3.87 (s, 3H), $3.79(\mathrm{~s}, 6 \mathrm{H}), 3.41(\mathrm{~s}, 3 \mathrm{H}) .{ }^{13} \mathrm{C} \mathrm{NMR}\left(75 \mathrm{MHz}^{\mathrm{CDCl}} 3\right)$ $\delta 153.9$ (2), 146.9, 145.4, 134.8, 134.4, 128.7, 128.5, 127.6, 126.7, 126.4, 123.5, 121.0, 112.5, 100.9 (2), $61.1,56.2(2)$, 41.0. IR (neat) $v_{\max } / \mathrm{cm}^{-1}: 1629,1589,1502,1240,1128,1005$. MS (APCI) m/z: $324[\mathrm{M}+\mathrm{H}]^{+}$. HRMS calcd for $\mathrm{C}_{20} \mathrm{H}_{22} \mathrm{NO}_{3}[\mathrm{M}+\mathrm{H}]^{+}$324.1600, obsd. 324.1602.

\subsection{N-(3-(benzyloxy)-4-methoxyphenyl)-3,4,5-trimethoxy-N-methylaniline $\mathbf{2 f}$}

Compound $2 f$ was prepared from diarylaniline 1 e (yield 61\%) according to literature [41]. ${ }^{1} \mathrm{H} \mathrm{NMR}\left(300 \mathrm{MHz}, \mathrm{CDCl}_{3}\right)$ א 7.40-7.27 (m, 5H), $6.86(\mathrm{~d}, 1 \mathrm{H}, J=8.4 \mathrm{~Hz}), 6.67-6.62(\mathrm{~m}, 2 \mathrm{H}), 6.06(\mathrm{~s}, 2 \mathrm{H}), 5.08(\mathrm{~s}, 2 \mathrm{H}), 3.88(\mathrm{~s}, 3 \mathrm{H}), 3.81(\mathrm{~s}, 3 \mathrm{H})$, $3.72(\mathrm{~s}, 6 \mathrm{H}), 3.20(\mathrm{~s}, 3 \mathrm{H}) .{ }^{13} \mathrm{C} \mathrm{NMR}\left(75 \mathrm{MHz}, \mathrm{CDCl}_{3}\right) \delta 153.6$ (2), 148.7, 146.1, 145.8, 142.9, 137.1, 128.6 (2), 127.9 , 127.4 (2), 115.1, 112.9, 110.1, 96.2 (2), 71.1, 61.1, 56.5, 56.1 (2), 41.0. IR (neat) $v_{\max } / \mathrm{cm}^{-1}: 1579,1502,1452,1411$, 1230, 1125. MS (ESI) m/z: $432.3[\mathrm{M}+\mathrm{Na}]^{+}$. HRMS calcd for $\mathrm{C}_{24} \mathrm{H}_{28} \mathrm{NO}_{5}[\mathrm{M}+\mathrm{H}]^{+} 410.1967$, obsd. 410.1964.

4.8. AzaisoCA-4 $2 \mathrm{~g}$

Compound $\mathbf{2 g}$ was prepared from diarylaniline $\mathbf{2 f}$ using $\mathrm{H}_{2}$ and $\mathrm{Pd} / \mathrm{C}$ (10 mol\%) in EtOAc (yield 98\%) according to literature[41]. ${ }^{1} \mathrm{H}$ NMR $\left(300 \mathrm{MHz}, \mathrm{CDCl}_{3}\right) \delta 6.79(\mathrm{~d}, 1 \mathrm{H}, J=8.7 \mathrm{~Hz}), 6.67(\mathrm{~d}, 1 \mathrm{H}, J=2.7 \mathrm{~Hz}), 6.53(\mathrm{dd}, 1 \mathrm{H}, J=8.7$ $\mathrm{Hz}, J=2.7 \mathrm{~Hz}), 6.14(\mathrm{~s}, 2 \mathrm{H}), 5.64(\mathrm{~s}, 1 \mathrm{H}), 3.87(\mathrm{~s}, 3 \mathrm{H}), 3.80(\mathrm{~s}, 3 \mathrm{H}), 3.77(\mathrm{~s}, 6 \mathrm{H}), 3.22(\mathrm{~s}, 3 \mathrm{H}) .{ }^{13} \mathrm{C} \mathrm{NMR}(75 \mathrm{MHz}$, $\left.\mathrm{CDCl}_{3}\right) \delta 153.6(2), 146.3,146.1,143.7,142.3,132.4,113.4,111.5,109.2,97.0$ (2), 61.1, 56.4, 56.2 (2), 41.0. IR (neat) $v_{\max } / \mathrm{cm}^{-1}: 2959,1581,1501,1447,1249$. MS (APCI) m/z: $342[\mathrm{M}+\mathrm{Na}]^{+}$. HRMS calcd for $\mathrm{C}_{17} \mathrm{H}_{22} \mathrm{NO}_{5}[\mathrm{M}+\mathrm{H}]^{+}$ 320.1498, obsd. 320.1494 .

\subsection{2-Methoxy-5-(methyl(3,4,5-trimethoxyphenyl)amino)phenyl acetate $\mathbf{2 h}$}

At $0^{\circ} \mathrm{C}$, to a solution of $\mathbf{2 g}(101 \mathrm{mg} ; 0.316 \mathrm{mmol})$ in $\mathrm{CH}_{2} \mathrm{Cl}_{2}(1 \mathrm{~mL})$ were added pyridine $(54 \mu \mathrm{L})$, and DMAP $(0.016$ mmol) and $\mathrm{Ac}_{2} \mathrm{O}(42 \mu \mathrm{L})$. After one hour of stirring, $\mathrm{H}_{2} \mathrm{O}(3 \mathrm{~mL})$ was added to the mixture. After extraction with EtOAc $(3 \times 3 \mathrm{~mL})$, the organic layer was dried, evaporated, and the residue was subjected to flash chromatography to give $2 \mathbf{h}$ as a yellow oil (76 mg, 67\%). ${ }^{1} \mathrm{H}$ NMR $\left(300 \mathrm{MHz}, \mathrm{CDCl}_{3}\right) \delta 6.92-6.84(\mathrm{~m}, 2 \mathrm{H}), 6.75(\mathrm{~d}, J=2.4 \mathrm{~Hz}, 1 \mathrm{H}), 6.17$ $(\mathrm{s}, 2 \mathrm{H}), 3.80(\mathrm{~s}, 6 \mathrm{H}), 3.77(\mathrm{~s}, 6 \mathrm{H}), 3.24(\mathrm{~s}, 3 \mathrm{H}), 2.28(\mathrm{~s}, 3 \mathrm{H}) .{ }^{13} \mathrm{C} \mathrm{NMR}\left(75 \mathrm{MHz}, \mathrm{CDCl}_{3}\right) \delta$ 169.0, 153.7 (2), 146.4 , 145.7, 142.9, 140.2, 132.8, 119.3, 116.8, 113.3, 97.4 (2), 61.1, 56.4, 56.2 (2), 40.9, 20.7. IR (neat) $v_{\max } / \mathrm{cm}^{-1}: 1721$, 1574, 1452, 1375, 1204. MS (ESI) $m / z: 362[\mathrm{M}+\mathrm{H}]^{+}$. HRMS calcd for $\mathrm{C}_{19} \mathrm{H}_{23} \mathrm{NO}_{6} \mathrm{Na}[\mathrm{M}+\mathrm{Na}]^{+} 384.1423$, obsd. 384.1426.

\subsection{N-(4-Chlorophenyl)-3,4,5-trimethoxy-N-methylaniline $\mathbf{2 i}$}

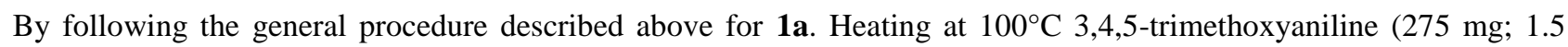
$\mathrm{mmol})$ and 1-chloro-4-iodobenzene $(59 \mathrm{mg} ; 0.25 \mathrm{mmol})$ in the presence of $\mathrm{Pd}(\mathrm{OAc})_{2}(22 \mathrm{mg} ; 10 \mathrm{~mol} \%)$, Xantphos (58 $\mathrm{mg} ; 10 \mathrm{~mol} \%)$ for $12 \mathrm{~h}$ gave $\mathbf{1 f}$ as an orange solid $(40 \mathrm{mg} ; 55 \%)$. m.p. $=109{ }^{\circ} \mathrm{C} .{ }^{1} \mathrm{H} \mathrm{NMR}\left(300 \mathrm{MHz}, \mathrm{CDCl}_{3}\right) \delta 7.20(\mathrm{~d}$, $2 \mathrm{H}, J=8.9 \mathrm{~Hz}), 6.95(\mathrm{~d}, 2 \mathrm{H}, J=8.9 \mathrm{~Hz}), 6.30(\mathrm{~s}, 2 \mathrm{H}), 3.82(\mathrm{~s}, 3 \mathrm{H}), 3.80(\mathrm{~s}, 6 \mathrm{H}), \mathrm{NH}$ not seen. ${ }^{13} \mathrm{C} \mathrm{NMR}(75 \mathrm{MHz}$, 
$\left.\mathrm{CDCl}_{3}\right) \delta 154.0$ (2), 142.5, 138.9, 133.3, 129.4 (2), 125.3, 118.6 (2), 96.8 (2), 61.1, 56.1 (2). IR (neat) $v_{\max } / \mathrm{cm}^{-1}: 1611$, 1590, 1508, 1228, 1119. MS (APCI) $\mathrm{m} / z: 294,296[\mathrm{M}+\mathrm{H}]^{+}$. By following the general procedure described above for $\mathbf{2 a}$. Diarylamine 1f $(29 \mathrm{mg} ; 0.1 \mathrm{mmol}), \mathrm{NaH}(5 \mathrm{mg} ; 0.2 \mathrm{mmol})$ and $\mathrm{CH}_{3} \mathrm{I}(28 \mathrm{mg} ; 0.2 \mathrm{mmol})$ gave $2 \mathbf{i}$ as a yellow-orange solid (27 mg; 88\%). m.p. $=91{ }^{\circ} \mathrm{C} .{ }^{1} \mathrm{H}$ NMR $\left(300 \mathrm{MHz}, \mathrm{CDCl}_{3}\right) \delta 7.17(\mathrm{~d}, 2 \mathrm{H}, J=8.5 \mathrm{~Hz}), 6.82(\mathrm{~d}, 2 \mathrm{H}, J=8.5 \mathrm{~Hz})$, $6.31(\mathrm{~s}, 2 \mathrm{H}), 3.84(\mathrm{~s}, 3 \mathrm{H}), 3.79$ (s, 6H), $3.26(\mathrm{~s}, 3 \mathrm{H}) .{ }^{13} \mathrm{C} \mathrm{NMR}\left(75 \mathrm{MHz}, \mathrm{CDCl}_{3}\right) \delta 153.9(2), 147.9,144.8,134.6,129.0$ (2), 124.6, 118.9 (2), 101.0 (2), 61.0, 56.1 (2), 40.6. IR (neat) $v_{\max } / \mathrm{cm}^{-1}: 2999,1609,1579,1510,1451,1237$.

\subsection{N,N,N'-Trimethyl-N'-(3,4,5-trimethoxyphenyl)benzene-1,4-diamine $\mathbf{2} \mathbf{j}$}

In a sealed tube and under an argon atmosphere were added successively, $\mathrm{Pd}_{2}(\mathrm{dba})_{3} . \mathrm{CHCl}_{3}(52 \mathrm{mg} ; 5 \mathrm{~mol} \%)$, Johnphos (30 mg; $10 \mathrm{~mol} \%$ ), dimethylamine (large excess), $2 \mathbf{i}$ (307 mg; $1 \mathrm{mmol}$ ), $\mathrm{NaO} t \mathrm{Bu}$ (134 mg; $1.4 \mathrm{mmol})$ in toluene (10 $\mathrm{mL}$ ). After heating at $100^{\circ} \mathrm{C}$ for $24 \mathrm{~h}$, the resulting suspension was cooled to room temperature and filtered through a pad of Celite eluting with ethyl acetate, and the inorganic salts were removed. The filtrate was concentrated and a rapid purification by silica gel column chromatography of the residue to eliminate the excess of 3,4,5-trimethoxyaniline gave the desired product $\mathbf{2} \mathbf{j}$ as a white solid $(98 \mathrm{mg}, 31 \%)$. m.p. $=75{ }^{\circ} \mathrm{C} .{ }^{1} \mathrm{H}$ NMR $\left(300 \mathrm{MHz}, \mathrm{CDCl}_{3}\right) \delta 7.05(\mathrm{~d}, 2 \mathrm{H}, J=7.3$ $\mathrm{Hz}), 6.75$ (d, 2H, J = $7.3 \mathrm{~Hz}), 6.01(\mathrm{~s}, 2 \mathrm{H}), 3.78(\mathrm{~s}, 3 \mathrm{H}), 3.76(\mathrm{~s}, 6 \mathrm{H}), 3.24(\mathrm{~s}, 3 \mathrm{H}), 2.95(\mathrm{~s}, 6 \mathrm{H}) .{ }^{13} \mathrm{C} \mathrm{NMR}(75 \mathrm{MHz}$, $\left.\mathrm{CDCl}_{3}\right) \delta 153.6$ (2), 147.9, 147.8, 146.9, 139.1, 126.0 (2), 113.9 (2), 93.8 (2), 61.2, 56.1 (2), 41.1 (2), 41.0. IR (neat) $v_{\max } / \mathrm{cm}^{-1}: 1611,1583,1504,1128$. MS (ESI) $m / z: 339[\mathrm{M}+\mathrm{Na}]^{+}$. HRMS calcd for $\mathrm{C}_{18} \mathrm{H}_{25} \mathrm{~N}_{2} \mathrm{O}_{3}[\mathrm{M}+\mathrm{H}]^{+} 317.1865$, obsd. 317.1860 .

\subsection{6-Methoxy-N-methyl-N-(3,4,5-trimethoxyphenyl)pyridin-3-amine $\mathbf{2 k}$}

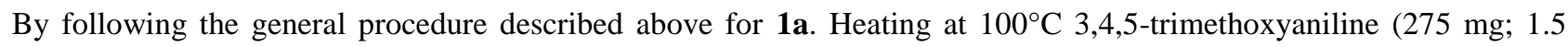
$\mathrm{mmol})$ and 5-bromo-2-methoxypyridine (187 mg; $1 \mathrm{mmol})$ in the presence of Pd(OAc) 2 (11 mg; $5 \mathrm{~mol} \%)$, Xantphos (29 $\mathrm{mg} ; 5 \mathrm{~mol} \%)$ for $5 \mathrm{~h}$ gave $1 \mathrm{~g}$ as a yellow oil (160 mg; 54\%). $\left.{ }^{1} \mathrm{H} \mathrm{NMR} \mathrm{(300} \mathrm{MHz}, \mathrm{CDCl}_{3}\right) \delta 7.98(\mathrm{~d}, 1 \mathrm{H}, J=2.3 \mathrm{~Hz})$, $7.42(\mathrm{dd}, 1 \mathrm{H}, J=8.8 \mathrm{~Hz}, J=2.8 \mathrm{~Hz}), 6.72(\mathrm{~d}, 1 \mathrm{H}, J=8.8 \mathrm{~Hz}), 6.10(\mathrm{~s}, 2 \mathrm{H}), 5.36(\mathrm{~s}, 1 \mathrm{H}), 3.92(\mathrm{~s}, 3 \mathrm{H}), 3.79$ (s, 3H), 3.78 (s, 6H). ${ }^{13} \mathrm{C} \mathrm{NMR}\left(75 \mathrm{MHz}, \mathrm{CDCl}_{3}\right) \delta 160.1,154.1$ (2), 141.2, 139.0, 133.5, 133.1, 132.2, 111.2, 93.9 (2), 61.2, 56.2 (2), 53.8. IR (neat) $v_{\max } / \mathrm{cm}^{-1}: 1599,1486,1367,1230,1125,1028$. MS (APCI) $m / z: 291[\mathrm{M}+\mathrm{H}]^{+}$. By following the general procedure described above for 2a. Diarylamine 1 g $(290 \mathrm{mg} ; 1 \mathrm{mmol})$, NaH (48 mg; $2 \mathrm{mmol})$ and CH 3 I (284 mg; 2 mmol) gave $2 \mathbf{k}$ as a yellow oil $(267 \mathrm{mg} ; 88 \%) .{ }^{1} \mathrm{H}$ NMR $\left(300 \mathrm{MHz}, \mathrm{CDCl}_{3}\right) \delta 7.93(\mathrm{~d}, 1 \mathrm{H}, J=2.8 \mathrm{~Hz}), 7.34(\mathrm{dd}, 1 \mathrm{H}, J$ $=8.8 \mathrm{~Hz}, J=2.8 \mathrm{~Hz}), 6.68(\mathrm{~d}, 1 \mathrm{H}, J=8.8 \mathrm{~Hz}), 6.03(\mathrm{~s}, 2 \mathrm{H}), 3.90(\mathrm{~s}, 3 \mathrm{H}), 3.76(\mathrm{~s}, 3 \mathrm{H}), 3.74(\mathrm{~s}, 6 \mathrm{H}), 3.22(\mathrm{~s}, 3 \mathrm{H}) .{ }^{13} \mathrm{C}$ NMR (75 MHz, $\left.\mathrm{CDCl}_{3}\right) \delta 160.2,153.7$ (2), 145.8, 141.2, 139.7, 134.9, 132.2, 111.2, 95.6 (2), 61.0, 56.1 (2), 53.6, 41.0. IR (neat) $v_{\max } / \mathrm{cm}^{-1}: 1587,1491,1275,1235,1127,1028$. MS (APCI) $m / z: 305[\mathrm{M}+\mathrm{H}]^{+}$. HRMS calcd for $\mathrm{C}_{16} \mathrm{H}_{21} \mathrm{~N}_{2} \mathrm{O}_{4}$ $[\mathrm{M}+\mathrm{H}]^{+}$305.1501, obsd. 305.1501 .

\subsection{N-Methyl-N-(3,4,5-trimethoxyphenyl)quinolin-3-amine $\mathbf{2 l}$}

By following the general procedure described above for 1a. Heating at $100^{\circ} \mathrm{C} \mathrm{3,4,5-trimethoxyaniline}(275 \mathrm{mg} ; 1.5$ mmol) and 3-bromoquinoline (207 mg; $1 \mathrm{mmol}$ ) in the presence of $\mathrm{Pd}(\mathrm{OAc})_{2}$ (44 mg; $\left.20 \mathrm{~mol} \%\right)$, Xantphos (29 mg; 5 mol\%) and $\mathrm{Cs}_{2} \mathrm{CO}_{3}(534 \mathrm{mg} ; 1.64 \mathrm{mmol})$ for $3 \mathrm{~h}$ gave $\mathbf{1 h}$ as a yellow oil $(167 \mathrm{mg} ; 54 \%) .{ }^{1} \mathrm{H} \mathrm{NMR}\left(300 \mathrm{MHz}, \mathrm{CDCl}_{3}\right)$ $\delta 8.69(\mathrm{~d}, 1 \mathrm{H}, J=2.7 \mathrm{~Hz}), 8.00-7.97(\mathrm{~m}, 1 \mathrm{H}), 7.64(\mathrm{~d}, 1 \mathrm{H}, J=2.7 \mathrm{~Hz}), 7.61-7.58(\mathrm{~m}, 1 \mathrm{H}), 7.50-7.40(\mathrm{~m}, 2 \mathrm{H}), 6.41(\mathrm{~s}$, $3 \mathrm{H}), 3.84(\mathrm{~s}, 3 \mathrm{H}), 3.77(\mathrm{~s}, 6 \mathrm{H}) .{ }^{13} \mathrm{C} \mathrm{NMR}\left(75 \mathrm{MHz} \mathrm{CDCl}_{3}\right) \delta 154.0$ (2), 144.9, 143.4, 138.2, 137.8, 133.6, 129.0, 129.0, 127.2, 126.4 (2), 116.7, 97.1 (2), 61.1, 56.1 (2). IR (neat) $v_{\max } / \mathrm{cm}^{-1}: 3338,1602,1506,1237,1124$. MS (APCI) $m / z$ : $311[\mathrm{M}+\mathrm{H}]^{+}$. By following the general procedure described above for 2a. Diarylamine $\mathbf{1 h}$ (155 mg; $\left.0.5 \mathrm{mmol}\right), \mathrm{NaH}(18$ 
mg; $0.75 \mathrm{mmol})$ and $\mathrm{CH}_{3} \mathrm{I}(107 \mathrm{mg} ; 0.75 \mathrm{mmol})$ gave $2 \mathrm{l}$ as a yellow oil $(110 \mathrm{mg} ; 68 \%) .{ }^{1} \mathrm{H} \mathrm{NMR}(300 \mathrm{MHz}, \mathrm{CDCl} 3)$ $\delta 8.62(\mathrm{~d}, 1 \mathrm{H}, J=2.8 \mathrm{~Hz}), 8.00-7.94(\mathrm{~m}, 1 \mathrm{H}), 7.68-7.63(\mathrm{~m}, 1 \mathrm{H}), 7.51-7.42(\mathrm{~m}, 2 \mathrm{H}), 7.39(\mathrm{~d}, 1 \mathrm{H}, J=2.8 \mathrm{~Hz}), 6.38(\mathrm{~s}$, 2H), 3.85 (s, 3H), 3.78 (s, 6H), $3.38(\mathrm{~s}, 3 \mathrm{H}) .{ }^{13} \mathrm{C}$ NMR (75 MHz, $\mathrm{CDCl}_{3}$ ) $\delta 154.1$ (2), 145.4, 144.2, 142.7, 142.6, 135.2, 129.0, 127.1, 126.5, 126.3, 117.3, 101.5 (2), 61.1, 56.2 (2), 40.82 (one C missing). IR (neat) $v_{\max } / \mathrm{cm}^{-1}: 1588,1504$, $1245,1229,1128 . \mathrm{MS}(\mathrm{APCI}) \mathrm{m} / z: 325[\mathrm{M}+\mathrm{H}]^{+}$.

\subsection{N,1-Dimethyl-N-(3,4,5-trimethoxyphenyl)-1H-indol-5-amine $\mathbf{2 m}$}

To an Emrys Optimizer were added 3,4,5-trimethoxyaniline (260 mg; $1.42 \mathrm{mmol}$ ), 6-bromo-1-methyl-1H-indole (150 $\mathrm{mg} ; 0.71 \mathrm{mmol}), \mathrm{Pd}(\mathrm{OAc})_{2}(16 \mathrm{mg} ; 10 \mathrm{~mol} \%)$, Xantphos (41 mg; $\left.10 \mathrm{~mol} \%\right), \mathrm{Cs}_{2} \mathrm{CO}_{3}$ (463 mg; $\left.1.42 \mathrm{mmol}\right)$ in dioxane $(5 \mathrm{~mL})$. The reaction vessel was then placed in the Emrys Optimizer and exposed to microwave irradiation according to the following specifications: temperature: $130^{\circ} \mathrm{C}$, time: $3 \mathrm{~h}$, fixed hold time: on, sample absorption: high, pre-stirring: 60 s. After cooling to room temperature, the mixture was filtered through a pad of Celite eluting with ethyl acetate, and the inorganic salts were removed. The filtrate was concentrated and a rapid purification by silica gel column chromatography of the residue to eliminate the excess of 3,4,5-trimethoxyaniline gave the desired product $1 \mathbf{i}$ as a yellow oil which was immediately engaged in the alkylation step. 1i: $(108 \mathrm{mg}, 49 \%)$; ${ }^{1} \mathrm{H} \mathrm{NMR}\left(300 \mathrm{MHz}, \mathrm{CDCl}_{3}\right) \delta 7.35(\mathrm{~s}$, 1H), $7.23(\mathrm{~s}, 1 \mathrm{H}), 7.05-7.02(\mathrm{~m}, 2 \mathrm{H}), 6.38(\mathrm{~d}, 1 \mathrm{H}, J=3.0 \mathrm{~Hz}), 6.15(\mathrm{~s}, 2 \mathrm{H}), 5.50$ (brs, 1H), 3.77 (s, 3H), 3.76 (s, 3H), $3.74(\mathrm{~s}, 6 \mathrm{H}) .{ }^{13} \mathrm{C} \mathrm{NMR}\left(75 \mathrm{MHz}, \mathrm{CDCl}_{3}\right) \delta 154.0$ (2), 143.0, 135.1, 133.8, 131.3, 129.6, 129.2, 117.9, 113.4, 110.0, 100.6, 93.3 (2), 61.2, 56.1 (2), 33.1. IR (neat) $v_{\max } / \mathrm{cm}^{-1}: 3370,1605,1505,1247,1125,1009$. MS (APCI) $\mathrm{m} / \mathrm{z}: 313$ $[\mathrm{M}+\mathrm{H}]^{+}$. By following the general procedure described above for 2a. Diarylamine 1i (31 mg; $\left.0.1 \mathrm{mmol}\right), \mathrm{NaH}(12 \mathrm{mg}$; $0.5 \mathrm{mmol})$ and $\mathrm{CH}_{3} \mathrm{I}(71 \mathrm{mg} ; 0.5 \mathrm{mmol})$ gave $\mathbf{2 m}$ as a yellow oil $(21 \mathrm{mg} ; 65 \%) .{ }^{1} \mathrm{H}$ NMR (300 MHz, $\left.\mathrm{CDCl}_{3}\right) \delta 7.43(\mathrm{~d}$, $1 \mathrm{H}, J=2.0 \mathrm{~Hz}), 7.30(\mathrm{~d}, 1 \mathrm{H}, J=8.6 \mathrm{~Hz}), 7.08-7.05(\mathrm{~m}, 2 \mathrm{H}), 6.45(\mathrm{~d}, 1 \mathrm{H}, J=3.0 \mathrm{~Hz}), 6.03(\mathrm{~s}, 2 \mathrm{H}), 3.81(\mathrm{~s}, 3 \mathrm{H}), 3.80(\mathrm{~s}$, 3H), 3.74 (s, 6H), 3.33 (s, 3H). ${ }^{13} \mathrm{C}$ NMR $\left(75 \mathrm{MHz} \mathrm{CDCl}_{3}\right) \delta 153.5$ (2), 147.4, 141.7, 134.4, 130.7, 129.6, 129.3, 120.7, 117.4, 110.1, 101.0, 93.6 (2), 61.1, 56.1 (2), 41.5, 33.1. IR (neat) $v_{\max } / \mathrm{cm}^{-1}: 1602,1581,1505,1490,1418,1234,1123$. MS (APCI) m/z: $327[\mathrm{M}+\mathrm{H}]^{+}$. HRMS calcd for $\mathrm{C}_{19} \mathrm{H}_{23} \mathrm{~N}_{2} \mathrm{O}_{3}[\mathrm{M}+\mathrm{H}]^{+}$327.1709, obsd.327.1698.

\subsection{N-(4-Methoxyphenyl)-N,1-dimethyl-1H-indol-5-amine $\mathbf{2 n}$}

By following the general procedure described above for 1 i. Heating at $130^{\circ} \mathrm{C}$ under microwave irradiation 4 methoxyaniline (123 mg; $1 \mathrm{mmol}$ ) and 6-bromo-1-methyl- $1 H$-indole (105 mg; $0.5 \mathrm{mmol}$ ) for $3 \mathrm{~h}$ gave $\mathbf{1 j}$ as a yellow oil (50 mg; 40\%). ${ }^{1} \mathrm{H}$ NMR (300 MHz, $\left.\mathrm{CDCl}_{3}\right) \delta 7.37(\mathrm{~d}, 1 \mathrm{H}, J=1.7 \mathrm{~Hz}), 7.30(\mathrm{~d}, 1 \mathrm{H}, J=8.7 \mathrm{~Hz}), 7.08-7.02(\mathrm{~m}, 4 \mathrm{H})$, 6.94-6.89 (m, 2H), $6.47(\mathrm{~d}, 1 \mathrm{H}, J=3.0 \mathrm{~Hz}), 5.31$ (br s, $1 \mathrm{H}), 3.86(\mathrm{~s}, 3 \mathrm{H}), 3.79(\mathrm{~s}, 3 \mathrm{H}) .{ }^{13} \mathrm{C} \mathrm{NMR}\left(75 \mathrm{MHz}, \mathrm{CDCl}_{3}\right)$ $\delta 153.7,139.5,136.9,133.2,129.4,129.2,118.6$ (2), 116.2, 114.7 (2), 110.6, 109.8, 100.3, 55.7, 32.9. IR (neat) $v_{\max } /$ $\mathrm{cm}^{-1}: 1618,1571,1509,1422,1240$. MS (APCI) $\mathrm{m} / z: 253[\mathrm{M}+\mathrm{H}]^{+}$. By following the general procedure described above for 2a. Diarylamine $\mathbf{1 j}$ (63 mg; $0.25 \mathrm{mmol}), \mathrm{NaH}$ (12 mg; $0.5 \mathrm{mmol})$ and $\mathrm{CH}_{3} \mathrm{I}(71 \mathrm{mg} ; 0.5 \mathrm{mmol})$ gave $2 \mathrm{n}$ as a white solid (34 mg; 51\%). m.p. $=113{ }^{\circ} \mathrm{C} ;{ }^{1} \mathrm{H}$ NMR (300 MHz, $\left.\mathrm{CDCl}_{3}\right) \delta 7.25$ (d, 1H, J=1.9 Hz), 7.17-7.14 (m, $\left.1 \mathrm{H}\right), 6.94(\mathrm{~d}$, $1 \mathrm{H}, J=2.9 \mathrm{~Hz}), 6.90(\mathrm{dd}, 1 \mathrm{H}, J=8.7 \mathrm{~Hz}, J=2.0 \mathrm{~Hz}), 6.78-6.69(\mathrm{~m}, 4 \mathrm{H}), 6.32(\mathrm{~d}, 1 \mathrm{H}, J=3.0 \mathrm{~Hz}), 3.68(\mathrm{~s}, 6 \mathrm{H}), 3.20(\mathrm{~s}$, 3H). ${ }^{13} \mathrm{C}$ NMR $\left(75 \mathrm{MHz}, \mathrm{CDCl}_{3}\right) \delta 153.4,144.9,143.0,133.7,129.5,129.3,119.2$ (2), 119.1, 114.8, 114.6 (2), 110.0 , 100.8, 55.8, 41.8, 33.0. IR (neat) $v_{\max } / \mathrm{cm}^{-1}: 1620,1508,1487,1422,1234,1031$. MS (APCI) $m / z: 267[\mathrm{M}+\mathrm{H}]^{+}$. HRMS calcd for $\mathrm{C}_{17} \mathrm{H}_{19} \mathrm{~N}_{2} \mathrm{O}[\mathrm{M}+\mathrm{H}]^{+}$267.1497, obsd. 267.1494.

4.16. N-(3,5-Dimethoxyphenyl)-N,1-dimethyl-1H-indol-5-amine 20 
By following the general procedure described above for $1 \mathbf{i}$. Heating at $130^{\circ} \mathrm{C}$ under microwave irradiation 3,5 dimethoxyaniline (153 mg; $1 \mathrm{mmol}$ ) and 6-bromo-1-methyl-1H-indole (105 mg; $0.5 \mathrm{mmol})$ for $3 \mathrm{~h}$ gave $1 \mathbf{k}$ as a yellow oil (35 mg; 25\%). ${ }^{1} \mathrm{H}$ NMR (300 MHz, $\left.\mathrm{CDCl}_{3}\right) \delta 7.45$ (d, 1H, J=1.9 Hz), $7.30(\mathrm{~d}, 1 \mathrm{H}, J=9.4 \mathrm{~Hz}), 7.13-7.07(\mathrm{~m}, 2 \mathrm{H})$, $6.45(\mathrm{~d}, 1 \mathrm{H}, J=3.0 \mathrm{~Hz}), 6.14(\mathrm{~d}, 2 \mathrm{H}, J=2.1 \mathrm{~Hz}), 6.01(\mathrm{t}, 1 \mathrm{H}, J=2.1 \mathrm{~Hz}), 5.68(\mathrm{br} \mathrm{s}, 1 \mathrm{H}), 3.81(\mathrm{~s}, 3 \mathrm{H}), 3.76(\mathrm{~s}, 6 \mathrm{H})$. ${ }^{13} \mathrm{C}$ NMR $\left(75 \mathrm{MHz}, \mathrm{CDCl}_{3}\right) \delta 161.2$ (2), 148.7, 134.2, 134.1, 129.6, 129.1, 118.6, 114.5, 109.9, 100.7, 93.6 (2), 91.3, 55.3 (2), 33.0. IR (neat) $v_{\max } / \mathrm{cm}^{-1}: 1592,1518,1448,1154$. MS (APCI) $m / z: 305[\mathrm{M}+\mathrm{Na}]^{+}$. By following the general procedure described above for 2a. Diarylamine 1k (28 mg; $0.1 \mathrm{mmol}), \mathrm{NaH}(12 \mathrm{mg} ; 0.5 \mathrm{mmol})$ and $\mathrm{CH}_{3} \mathrm{I}(71 \mathrm{mg}$; 0.5 mmol) gave 20 as a yellow oil (27 mg; 93\%). ${ }^{1} \mathrm{H}$ NMR $\left(300 \mathrm{MHz}, \mathrm{CDCl}_{3}\right) \delta 7.47(\mathrm{~d}, 1 \mathrm{H}, J=2.0 \mathrm{~Hz}), 7.32(\mathrm{~d}, 1 \mathrm{H}, J=$ $8.6 \mathrm{~Hz}), 7.09(\mathrm{~d}, 2 \mathrm{H}, J=6.9 \mathrm{~Hz}, J=2.5 \mathrm{~Hz}), 6.46(\mathrm{~d}, 1 \mathrm{H}, J=3.1 \mathrm{~Hz}), 5.94(\mathrm{~s}, 3 \mathrm{H}), 3.81(\mathrm{~s}, 3 \mathrm{H}), 3.70(\mathrm{~s}, 6 \mathrm{H}), 3.32(\mathrm{~s}$, 3H). ${ }^{13} \mathrm{C} \mathrm{NMR}\left(75 \mathrm{MHz}, \mathrm{CDCl}_{3}\right) \delta 161.4$ (2), 152.5, 141.2, 134.8, 129.6, 129.3, 121.5, 118.9, 110.2, 101.1, 93.6 (2), 89.6, 55.3 (2), 41.2, 33.1. IR (neat) $v_{\max } / \mathrm{cm}^{-1}: 3433,1608,1578,1419,1236,1138$. MS (APCI) m/z: $297[\mathrm{M}+\mathrm{H}]^{+}$. HRMS calcd for $\mathrm{C}_{18} \mathrm{H}_{21} \mathrm{~N}_{2} \mathrm{O}_{2}[\mathrm{M}+\mathrm{H}]^{+}$297.1603, obsd. 297.1601.

\subsection{N-Methyl-1-(phenylsulfonyl)-N-(3,4,5-trimethoxyphenyl)-1H-indol-5-amine 2p}

By following the general procedure described above for 1i. Heating at $130^{\circ} \mathrm{C}$ under microwave irradiation $3,4,5$ trimethoxyaniline (183 mg; $1 \mathrm{mmol}$ ) and 5-bromo-1-(phenylsulfonyl)-1H-indole (167 mg; $0.5 \mathrm{mmol})$ for $4 \mathrm{~h}$ gave 11 as a yellow oil (162 mg; 74\%). ${ }^{1} \mathrm{H}$ NMR (300 MHz, $\left.\mathrm{CDCl}_{3}\right) \delta$ 7.89-7.84 (m, 3H), 7.53-7.47 (m, 2H), 7.43-7.37 (m, $\left.2 \mathrm{H}\right)$, $7.17(\mathrm{~d}, 1 \mathrm{H}, J=2.0 \mathrm{~Hz}), 7.02(\mathrm{dd}, 1 \mathrm{H}, J=2.1 \mathrm{~Hz}, J=8.8 \mathrm{~Hz}), 6.53(\mathrm{dd}, 1 \mathrm{H}, J=3.6 \mathrm{~Hz}, J=0.5 \mathrm{~Hz}), 6.26(\mathrm{~s}, 2 \mathrm{H}), 5.74$ $(\mathrm{s}, 1 \mathrm{H}), 3.80(\mathrm{~s}, 3 \mathrm{H}), 3.74(\mathrm{~s}, 6 \mathrm{H}) .{ }^{13} \mathrm{C} \mathrm{NMR}\left(75 \mathrm{MHz}, \mathrm{CDCl}_{3}\right) \delta 153.9(2), 140.3,139.8,138.2,133.8,132.5,131.9$, 130.2, 129.2 (2), 127.0, 126.7 (2), 117.4, 114.3, 109.9, 109.3, 95.6 (2), 61.0, 56.0 (2). IR (neat) $v_{\max } / \mathrm{cm}^{-1}: 2927,1600$, 1504, 1450, 1336, 1227. MS (ESI) $\mathrm{m} / z: 461[\mathrm{M}+\mathrm{Na}]^{+}$. By following the general procedure described above for $\mathbf{2 a}$. Diarylamine 11 (110 mg; $0.25 \mathrm{mmol}), \mathrm{NaH}$ (12 mg; $0.5 \mathrm{mmol})$ and $\mathrm{CH}_{3} \mathrm{I}$ (71 mg; $\left.0.5 \mathrm{mmol}\right)$ gave $2 \mathbf{p}$ as a yellow oil (81 mg; 72\%). ${ }^{1} \mathrm{H}$ NMR (300 MHz, $\left.\mathrm{CDCl}_{3}\right) \delta$ 7.89-7.86 (m, 3H), 7.55-7.50 (m, 2H), $7.42(\mathrm{dd}, 2 \mathrm{H}, J=10.4 \mathrm{~Hz}, J=4.7 \mathrm{~Hz}$ ), $7.13(\mathrm{~d}, 1 \mathrm{H}, J=2.2 \mathrm{~Hz}), 7.02(\mathrm{dd}, 1 \mathrm{H}, J=8.9 \mathrm{~Hz}, J=2.2 \mathrm{~Hz}), 6.57(\mathrm{~d}, 1 \mathrm{H}, J=3.6 \mathrm{~Hz}), 6.16(\mathrm{~s}, 2 \mathrm{H}), 3.82(\mathrm{~s}, 3 \mathrm{H}), 3.73$ (s, 6H), 3.28 (s, 3H). ${ }^{13} \mathrm{C} \mathrm{NMR}\left(75 \mathrm{MHz}, \mathrm{CDCl}_{3}\right) \delta 153.7$ (2), 146.1, 145.7, 138.3, 133.8, 133.0, 131.9, 130.4, 129.3 (2), 127.0, 126.8 (2), 119.6, 114.2, 112.7, 109.4, 98.0 (2), 61.1, 56.1 (2), 41.2. IR (neat) $v_{\max } / \mathrm{cm}^{-1}: 1586,1504,1446,1368$, 1123. MS (ESI) $m / z: 453[\mathrm{M}+\mathrm{H}]^{+}, 475[\mathrm{M}+\mathrm{Na}]^{+} \cdot \mathrm{HRMS}$ calcd for $\mathrm{C}_{25} \mathrm{H}_{27} \mathrm{~N}_{2} \mathrm{O}_{5} \mathrm{~S}[\mathrm{M}+\mathrm{H}]^{+} 453.1484$, obsd.453.1487.

\subsection{NN-Methyl-N-(3,4,5-trimethoxyphenyl)-1H-indol-5-amine $\mathbf{2 q}$}

A THF (1 mL) solution of $\mathbf{2 p}(47 \mathrm{mg} ; 0.1 \mathrm{mmol})$ was added $0.5 \mathrm{~mL}$ of a TBAF solution in THF (0.5 mmol) and stirred at $100{ }^{\circ} \mathrm{C}$ for $6 \mathrm{~h}$. After cooling, the solution was filtered through a pad of Celite, eluting with ethyl acetate. The filtrate was concentrated and a purification by silica gel column chromatography gave the desired product $\mathbf{2 q}$ as a white solid (15 mg, 49 \%). m.p. $166{ }^{\circ} \mathrm{C} .{ }^{1} \mathrm{H}$ NMR $\left(300 \mathrm{MHz}, \mathrm{CDCl}_{3}\right) \delta 8.34(\mathrm{~s}, 1 \mathrm{H}), 7.44(\mathrm{~s}, 1 \mathrm{H}), 7.36(\mathrm{~d}, 1 \mathrm{H}, J=8.6 \mathrm{~Hz}), 7.22(\mathrm{t}$, $1 \mathrm{H}, J=2.7 \mathrm{~Hz}), 7.02(\mathrm{dd}, 1 \mathrm{H}, J=8.6 \mathrm{~Hz}, J=1.9 \mathrm{~Hz}), 6.52-6.51(\mathrm{~m}, 1 \mathrm{H}), 6.04(\mathrm{~s}, 2 \mathrm{H}), 3.80(\mathrm{~s}, 3 \mathrm{H}), 3.74(\mathrm{~s}, 6 \mathrm{H}), 3.33$ (s, 3H). ${ }^{13} \mathrm{C}$ NMR $\left(75 \mathrm{MHz}, \mathrm{CDCl}_{3}\right) \delta 153.6$ (2), 147.4, 142.1, 133.4, 130.8, 128.8, 125.1, 121.0, 117.1, 112.0, 102.7, 93.8 (2), 61.2, 56.1 (2), 41.5. IR (neat) $v_{\max } / \mathrm{cm}^{-1}: 3433,1608,1578,1505,1450,1419,1236$. MS (ESI) $\mathrm{m} / z: 335$ $[\mathrm{M}+\mathrm{Na}]^{+}$. HRMS calcd for $\mathrm{C}_{18} \mathrm{H}_{21} \mathrm{~N}_{2} \mathrm{O}_{3}[\mathrm{M}+\mathrm{H}]^{+}$313.1552, obsd. 331.1548 .

4.19. N-(3-(benzyloxy)-4-methoxyphenyl)-3,4,5-trimethoxy-N-propylaniline 3a

To a diarylamine 1e $(197 \mathrm{mg} ; 0.5 \mathrm{mmol})$ solution in DMF $(5 \mathrm{~mL})$ was added at $0^{\circ} \mathrm{C}, \mathrm{NaH}(24 \mathrm{mg} ; 1 \mathrm{mmol})$, and 1 bromopropane $(122 \mathrm{mg} ; 1 \mathrm{mmol})$. The mixture was stirred at r.t. for $2 \mathrm{~h}$, diluted in EtOAc $(5 \mathrm{~mL})$ and washed with 
aqueous $\mathrm{NaHCO}_{3}$. The organic layer was dried, evaporated, and the residue was subjected to flash chromatography to give 3a as a brown oil (208 mg, 95\%). ${ }^{1} \mathrm{H}$ NMR (300 MHz, $\left.\mathrm{CDCl}_{3}\right) \delta$ 7.40-7.27 (m, 5H), 6.86-6.83 (m, 1H), 6.63-6.59 $(\mathrm{m}, 2 \mathrm{H}), 6.00(\mathrm{~s}, 2 \mathrm{H}), 5.09(\mathrm{~s}, 2 \mathrm{H}), 3.89(\mathrm{~s}, 3 \mathrm{H}), 3.80(\mathrm{~s}, 3 \mathrm{H}), 3.71(\mathrm{~s}, 6 \mathrm{H}), 3.50-3.44(\mathrm{~m}, 2 \mathrm{H}), 1.61-1.59(\mathrm{~m}, 2 \mathrm{H}), 0.89$ $(\mathrm{t}, 3 \mathrm{H}, J=7.4 \mathrm{~Hz}) .{ }^{13} \mathrm{C} \mathrm{NMR}\left(75 \mathrm{MHz}, \mathrm{CDCl}_{3}\right) \delta 153.7$ (2), 148.7, 145.8, 145.4, 141.6, 137.1, 131.8, 128.6 (2), 127.9, 127.4 (2), 116.0, 112.8, 111.0, 96.3 (2), 71.1, 61.2, 56.5, 56.1 (2), 54.7, 21.0, 11.6. IR (neat) $v_{\max } / \mathrm{cm}^{-1}: 2925,1610$, 1502, 1464, 1225, 1127. MS (APCI) $m / z: 438[\mathrm{M}+\mathrm{H}]^{+}$. HRMS calcd for $\mathrm{C}_{26} \mathrm{H}_{32} \mathrm{NO}_{5}[\mathrm{M}+\mathrm{H}]^{+}$438.2280, obsd. 438.2285 .

\subsection{2-methoxy-5-(propyl(3,4,5-trimethoxyphenyl)amino)phenol 3b}

3b brown oil (140 mg; 99\%) was prepared by following the general procedure described above for $2 \mathrm{~g} .{ }^{1} \mathrm{H}$ NMR $(300$ $\left.\mathrm{MHz} \mathrm{CDCl}_{3}\right) \delta 6.78(\mathrm{~d}, 1 \mathrm{H}, J=8.7 \mathrm{~Hz}), 6.65(\mathrm{~d}, 1 \mathrm{H}, J=2.6 \mathrm{~Hz}), 6.51(\mathrm{dd}, 1 \mathrm{H}, J=8.7 \mathrm{~Hz}, J=2.6 \mathrm{~Hz}), 6.11(\mathrm{~s}, 2 \mathrm{H})$, $5.60(\mathrm{~s}, 1 \mathrm{H}), 3.88(\mathrm{~s}, 3 \mathrm{H}), 3.81(\mathrm{~s}, 3 \mathrm{H}), 3.77(\mathrm{~s}, 6 \mathrm{H}), 3.57-3.52(\mathrm{~m}, 2 \mathrm{H}), 1.70-1.60(\mathrm{~m}, 2 \mathrm{H}), 0.94(\mathrm{t}, 3 \mathrm{H}, J=7.4 \mathrm{~Hz}) .{ }^{13} \mathrm{C}$ NMR $\left(75 \mathrm{MHz}, \mathrm{CDCl}_{3}\right) \delta 153.7$ (2), 146.3, 145.2, 142.6, 142.2, 132.3, 114.1, 111.6, 109.7, 97.5 (2), 61.2, $56.4,56.2$ (2), 54.7, 21.0, 11.6. IR (neat) $v_{\max } / \mathrm{cm}^{-1}: 2959,1581,1501,1466,1261,1126,1027 . \mathrm{MS}(\mathrm{ESI}) \mathrm{m} / \mathrm{z}: 370[\mathrm{M}+\mathrm{Na}]^{+}$. HRMS calcd for $\mathrm{C}_{19} \mathrm{H}_{26} \mathrm{NO}_{5}[\mathrm{M}+\mathrm{H}]^{+} 348.1811$, obsd. 348.1812 .

\subsection{1-Methyl-N-propyl-N-(3,4,5-trimethoxyphenyl)-1H-indol-5-amine 3c}

3c yellow oil (120 mg; 34\%) was prepared from 1i by following the general procedure described above for 3a. ${ }^{1} \mathrm{H}$ NMR $\left(300 \mathrm{MHz}, \mathrm{CDCl}_{3}\right) \delta 7.45(\mathrm{~d}, 1 \mathrm{H}, J=1.7 \mathrm{~Hz}), 7.32(\mathrm{~d}, 1 \mathrm{H}, J=8.6 \mathrm{~Hz}), 7.08-7.05(\mathrm{~m}, 2 \mathrm{H}), 6.47(\mathrm{~d}, 1 \mathrm{H}, J=3.0 \mathrm{~Hz})$, $5.99(\mathrm{~s}, 2 \mathrm{H}), 3.81(\mathrm{~s}, 6 \mathrm{H}), 3.73(\mathrm{~s}, 6 \mathrm{H}), 3.66(\mathrm{t}, 2 \mathrm{H}, J=6.5 \mathrm{~Hz}), 1.76-1.60(\mathrm{~m}, 2 \mathrm{H}), 0.97(\mathrm{t}, 3 \mathrm{H}, J=7.4 \mathrm{~Hz}) .{ }^{13} \mathrm{C} \mathrm{NMR}$ (75 MHz, $\left.\mathrm{CDCl}_{3}\right) \delta 153.5$ (2), 146.7, 139.9, 134.5, 130.2, 129.4, 129.3, 121.8, 118.7, 110.1, 100.9, 93.3 (2), $61.1,56.0$ (2), 55.0, 33.0, 21.0, 11.6. IR (neat) $v_{\max } / \mathrm{cm}^{-1}: 1606,1580,1507,1487,1237,1125$. MS (ESI) $\mathrm{m} / z: 377[\mathrm{M}+\mathrm{Na}]^{+}$. HRMS calcd for $\mathrm{C}_{21} \mathrm{H}_{27} \mathrm{~N}_{2} \mathrm{O}_{3}[\mathrm{M}+\mathrm{H}]^{+}$355.2022, obsd. 355.2018.

\subsection{Biolology}

\subsubsection{Cell Culture and Proliferation Assay}

Cancer cell lines were obtained from the American type Culture Collection (Rockville, MD) and were cultured according to the supplier's instructions. Briefly, A549 lung carcinoma, U87-MG human glioblastoma, MDA-MB231 cells were grown in Dulbecco minimal essential medium (DMEM) containing $4.5 \mathrm{~g} / \mathrm{L}$ glucose supplemented with $10 \%$ FCS and 1\% glutamine. Human K562 leukemia and HCT116 colorectal carcinoma cells were grown in RPMI 1640 containing 10\% FCS and 1\% glutamine. Human umbilical vein endothelial cells (HUVECs) were obtained from Clonetics (Lonza, Walkersville, MD, USA) and cultured according to the supplier's instructions. Briefly, HUVECs from three to six passages were subcultured to confluence onto $0.2 \%$ gelatin coated tissue culture flasks in endothelial cell growth medium (EGM2) containing growth factors and $2 \%$ FCS. All cell lines were maintained at $37{ }^{\circ} \mathrm{C}$ in a humidified atmosphere containing $5 \% \mathrm{CO}_{2}$. Cell viability was assessed using Promega CellTiter-Blue TM reagent according to the manufacturer's instructions. Cells were seeded in 96 -well plates $(5 \times 103$ cells/well $)$ containing $50 \mu \mathrm{L}$ growth medium. After $24 \mathrm{~h}$ of culture, the cells were supplemented with $50 \mu \mathrm{L}$ of the tested compound dissolved in DMSO (less than $0.1 \%$ in each preparation). After $72 \mathrm{~h}$ of incubation, $20 \mu \mathrm{L}$ of resazurin was added for $2 \mathrm{~h}$ before recording fluorescence $(\lambda \mathrm{ex}=560 \mathrm{~nm}, \lambda \mathrm{em}=590 \mathrm{~nm})$ using a Victor microtiter plate fluorimeter (Perkin-Elmer,USA). The IC50 corresponds to the concentration of the tested compound that caused a decrease of $50 \%$ in fluorescence of drug treated cells compared with untreated cells. Experiments were performed in triplicate.

\subsubsection{Tubulin Binding Assay}


Sheep brain tubulin was purified according to the method of Shelanski [42] by two cycles of assembly-disassembly and then diluted in the assembly buffer containing 0.1 M MES, $0.5 \mathrm{mM} \mathrm{MgCl} 2,1 \mathrm{mM}$ EGTA, and $1 \mathrm{mM}$ GTP, pH 6.6 to a final concentration around 2-3 mg/mL. Tubulin assembly was monitored by fluorescence according to reported procedure [43] using DAPI as fluorescent molecule. Assays were realized on 96-well plates prepared with Biomek NKMC and Biomek 3000 from Beckman Coulter and read at $37^{\circ} \mathrm{C}$ on Wallac Victor fluorimeter from Perkin Elmer. The $\mathrm{IC}_{50}$ value of each compound was determined as the concentration required to decrease the maximum assembly rate of tubulin by $50 \%$ compared to the rate in the absence of compound. The $\mathrm{IC}_{50}$ values for all compounds were compared to the $\mathrm{IC}_{50}$ of isoCA-4 and isoerianin measured the same day under the same conditions.

\subsubsection{Cell Cycle Analysis}

Exponentially growing cancer cells (K562, HCT116) were incubated with tested compound or DMSO for 24 h. Cellcycle profiles were determined by flow cytometry on a FC500 flow cytometer (Beckman-Coulter, France) as described previously.[44]

\subsubsection{Apoptosis Assay}

Apoptosis was measured by the Apo-one homogeneous caspase-3/7 assay (Promega Co, WI) according to the manufacturer's recommendations. Briefly, cells were subcultured on a 96 -well plate with $5 \times 10^{4}$ cells/well in $100 \mu \mathrm{L}$ medium. After $24 \mathrm{~h}$ of incubation, the medium in the 96-well plate was discarded and replaced with medium containing different concentrations of $\mathbf{2 b}$ and $\mathbf{2 m}(7.5,15,25$ and $50 \mathrm{nM})$. The treated cells were incubated for $24 \mathrm{~h}$, each well then received $100 \mu \mathrm{L}$ of a mixture of caspase substrate and Apo-one caspase 3/7 buffer. After $1 \mathrm{~h}$ of incubation, the fluorescence of sample was measured using a Victor microtiter plate fluorimeter (Perkin-Elmer, USA) at $527 \mathrm{~nm}$.

\subsubsection{Inhibition of endothelial tube formation using ECFCs.}

The protocol was achieved according to ref. [38].

\subsubsection{Cord Disruption Assay}

HUVECs $\left(2 \times 10^{4}\right.$ cells per well) were plated in 96-well plates on a thick layer of Matrigel (Becton Dickinson; $10 \mathrm{mg}$ $\mathrm{mL}^{-1}, 60 \mu \mathrm{L}$ per well) and allowed to align for $24 \mathrm{~h}$. $\mathbf{2 b}, \mathbf{2 m}$ or vehicle (DMSO) were added to the formed cords and left for $3 \mathrm{~h}$. Images were taken $3 \mathrm{~h}$ after the addition of compounds.

\subsubsection{Molecular Modelling}

Coordinates for compounds $\mathbf{2 b}, \mathbf{2 m}$ and isoCA-4 were generated using CORINA v3.44 software.[45] Molecules were then freely docked in the colchicine binding site between chains C and D from PDB structure 1SA0 using GOLD v5.1 software.[46] CHEMPLP with default parameters was used as an objective function.[47] Structures of the complexes were exported for further examination and depiction with Chimera v1.8.1 software,[48] including hydrogen bonds detection, close contact analysis and representation of the solvent-accessible surface colored according to polarity.

\section{Acknowledgments}

The CNRS (Centre National de la Recherche Scientifique) is gratefully acknowledged for financial support of this research. We also thank ARC (association pour la recherche sur le cancer), for their financial support of this research (doctoral fellowship to M.A. Soussi). OIDD screening data supplied courtesy of Eli Lilly and Company - used with Lilly's permission. Our laboratory BioCIS-UMR 8076 is a member of the Laboratory of Excellence LERMIT supported 
by a grant from ANR (Agence Nationale de la Recherche, ANR-10-LABX-33). This work on tubulin was supported by a grant from ANR (ANR-09-BLAN-0071).

\section{References}

[1] G. R. Pettit, S.B. Singh, E. Hamel, C.M. Lin, D.S. Alberts, D. Garcia-Kendall, Experientia 45 (1989) $209-211$.

[2] C. M. Lin, H. H. Ho, G. R. Pettit, E. Hamel, Biochemistry 28 (1989) 6984-6991.

[3] A. T. Mc Gown, B. W. Fox, Cancer Chemother. Pharmacol. 26 (1990) 79-81.

[4] G. G. Dark, S. A. Hill, V. E. Prise, G. M. Tozer, G. R. Pettit, D. J. Chaplin, Cancer Res. 57 (1997) 1829-1834.

[5] S. L. Young, D. J. Chaplin, Expert Opin. Investig. Drugs 13 (2004) 1171-1182.

[6] K. Ohsumi,T. Hatanaka, R. Nakagawa, Y. Fukuda, Y.; Morinaga, Y.; Y. Suga, Y. Nihei, K.Ohishi, Y. Akiyama, T. Tsuji, Anti-Cancer Drug Design 14 (1999) 539-548.

[7] G. J. Rustin, G. Shreeves, P. D. Nathan, A. Gaya, T. S. Ganesan, D. Wang, J. Boxall, L. Poupard, D. J. Chaplin, M. R. L. Stratford, J. Balkissoon, M. Zweifel, Br. J. Cancer 102 (2010) 1355-1360.

[8] P. Nathan, M. Zweifel, A.R. Padhani, D.M. Koh, M. Ng, D.J. Collins, A. Harris, C. Carden, J. Smythe, N. Fisher, N.J. Taylor, J.J. Stirling, S.P. Lu, M.O. Leach, G.J. Rustin, Judson. Clin Cancer Res. 18 (2012) 3428-39.

[9] K.Ohsumi, T. Hatanaka, R. Fujita, R.Nakagawa, Y. Fukuda, Y. Nihei, Y. Suga, Y. Morinaga, Y. Akiyama, T. Tsuji, Bioorg. Med. Chem. Lett. 8 (1998) 3153-3158.

[10] Aprile, E. Del Grosso, G.C. Tron, G. Grosa, Drug Metab. Dispos. 35 (2007) 2252-2261.

[11] O. Provot, A. Hamze, J.-F. Peyrat, J.-D. Brion, M. Alami, Anticancer Agents Med Chem. 13 (2013) 1614-1635.

[12] C. Mousset, A. Giraud, O. Provot, A. Hamze, J. Bignon, J.-M. Liu, S. Thoret, J. Dubois, J.-D. Brion, M. Alami, Bioorg Med Chem Lett 18 (2008) 3266-3271.

[13] E. Rasolofonjatovo, O. Provot, A. Hamze, J. Bignon, S. Thoret, J.-D. Brion, M. Alami, Eur. J. Med. Chem. 45, (2010) $3617-3626$.

[14] O. Provot, A. Giraud, J.-F. Peyrat, M. Alami, J.-D. Brion, Tetrahedron Lett. 46 (2005) 8547-8550.

[15] C. Mousset, O. Provot, A. Hamze, J. Bignon, J.-D. Brion, M. Alami, Tetrahedron 64 (2008) 4287-4294.

[16] N. L'Hermite, A. Giraud, O. Provot, J.-F. Peyrat, M. Alami, J.-D Brion, Tetrahedron 62 (2006) 11994-12002.

[17] A. Giraud, O. Provot, J.-F. Peyrat, M. Alami, J.-D. Brion, Tetrahedron 62 (2006) 7667-7673.

[18] J. Aziz, E. Brachet, A. Hamze, J.-F. Peyrat, G. Bernadat, E.Morvan, J. Bignon, J.-M. Liu, J. Wdzieczak-Bakala, D. Desravines, J. Dubois, M. Tueni, A.Yassine, J.-D. Brion, M. Alami Org. Biomol. Chem. 11 (2013) 430-442.

[19] M. Lawson, A. Hamze, J.-F. Peyrat, J. Bignon, J. Dubois, J.-D. Brion, M. Alami.Org. Biomol. Chem. 11 (2013) $3664-3673$.

[20] S. Messaoudi, B. Tréguier, A. Hamze, O. Provot, J.-F. Peyrat, J.R. Rodrigo De Losada, J.-M. Liu, J. Bignon, J. Wdzieczak-Bakala, S. Thoret, J. Dubois, J.-D. Brion, M. Alami, J. Med. Chem. 52 (2009) 4538-4542.

[21] A. Hamze, A. Giraud, S. Messaoudi, O. Provot, J.-F. Peyrat, J. Bignon, J.-M. Liu, J. Wdzieczak-Bakala, S. Thoret, J. Dubois, J.-D. Brion, M. Alami, ChemMedChem 4 (2009) 1912-1924.

[22] M.A. Soussi, S. Aprile, S. Messaoudi, O. Provot, E. Del Grosso, J. Bignon, J. Dubois, J.-D. Brion, G. Grosa, M. Alami, ChemMedChem 6 (2011) 1781-1788.

[23] A. Hamze, D. Veau, O. Provot, J.-D. Brion, M. Alami, J. Org. Chem. 74 (2009) 1337-1340.

[24] E. Rasolofonjatovo, B. Tréguier, O. Provot, H. Hamze, E. Morvan, J.-D. Brion, M. Alami, Tetrahedron Lett. 52 (2011) $1036-1040$.

[25] A. Hamze, , J.-D. Brion, M. Alami, Org. Lett. 14 (2012) 2782-2785.

[26] A. Hamze, E. Rasolofonjatovo, O. Provot, C. Mousset, D. Veau, J. Rodrigo, J. Bignon, J.-M; Liu, J. Wdzieczak-Bakala, S. Thoret, J. Dubois, J.-D. Brion, M. Alami, ChemMedChem 6 (2011) 2179-2191.

[27] S. Messaoudi, A. Hamze, O. Provot, B. Tréguier, J. Rodrigo De Losada, J. Bignon, J.-M. Liu, J. Wdzieczak-Bakala, S. Thoret, J. Dubois, J.-D. Brion, M. Alami, ChemMedChem 6 (2011) 488-497.

[28] A. Schlapbach, R. Heng, F.D. Padova Bioorg. Med. Chem. Lett., 14 (2004), 357-360

[29] K. Ohta, Y. Chiba, T. Ogawa, Y. Endo, Bioorg. Med. Chem. Lett., 18 (2008), 5050-5053

[30] S. Messaoudi, D. Audisio, J.-D. Brion, M. Alami, Tetrahedron, 63 (2007) 10202-10210.

[31] D. Audisio, S. Messaoudi, J.-F. Peyrat, J.-D. Brion, M. Alami, Tetrahedron. Lett., 48 (2007) 6928-6932.

[32] M. A. Soussi, D. Audisio, S. Messaoudi, O. Provot, J.-D. Brion, M. Alami, Eur. J. Org. Chem. (2011), 5077-5088

[33] E. Brachet, J. F. Peyrat, J.-D. Brion, S. Messaoudi, M. Alami, Org. Biomol. Chem. 11 (2013), 3808-3816.

[34] R. Shirai, K. Tokuda, Y. Koiso, S. Iwasaki, Bioorg. Med. Chem. Lett. 4 (1994) 699-704.

[35] R. B.; Bedford, M. E. Blake, Adv. Synth. Catal. 345, (2003) 1107-1110.

[36] Giraud, O. Provot, A. Hamze, J. D. Brion, M. Alami, Tetrahedron Lett. 49 (2008) 1107-1110.

[37] A.B.S. Maya, C. Pérez-Melaro, C. Mateo, D. Alonso, J.L. Fernàndez, C.Gajate, F. Mollinedo, R. Pelàez, E. Caballero, M. Medarde, J. Med. Chem. 48 (2005) 556-568.

[38] J. A. Lee, S. Chu, F.S. Willard, K.L. Cox, R.J. Sells Galvin, R.B. Peery, S.E. Oliver, J. Oler, T.D. Meredith, S.A. Heider, W.H. Gough, S. Husain, A.D. Palkowitz, C.M. Moxham, J. Biomol. Screen. 16 (2011) 587-602.

[39] K.A. Hotchkiss, A.W. Ashton, R. Mahmood, R.G. Russel, J.A. Sparano, E.L. Schwartz, Mol. Cancer Ther. 1 (2002) 1191-1200

[40] R.B.G. Ravelli, B. Gigand, P.A. Curmi, I. Jourdain, S. Lachkar, A. Sobel, M. Knossov, Nature 428 (2004) 198-202.

[41] M. Alami, S. Messaoudi, A. Hamze, O. Provot, J.-D. Brion, J.-M. Liu, J. Bignon, J.; Bakala, PCT WO $2009 / 147217$ A1.

[42] M.L. Shelanski, F. Gaskin, C.R. Cantor, Proc. Natl. Acad. Sci. USA 70 (1973) 765-768.

[43] D.M. Barron, S.K. Chatterjee, R. Ravindra, R. Roof, E. Baloglu, D.G.I. Kingston, S. Bane, Anal. Biochem. 315 (2003) $49-56$.

[44] C. Venot, M. Maratrat, C. Dureuil, E. Conseiller, L. Bracco, L. Debussche, EMBO J. 17 (1998) $4668-4679$.

[45] J. Sadowski, J. Gasteiger, G. Klebe, J. Chem. Inf. Comput. Sci. 34 (1994) 1000-1008.

[46] G. Jones, P. Willett, R. C. Glen, A. R. Leach, R. Taylor, J. Mol. Biol. 267 (1997) 727-748.

[47] O. Korb, T. Stützle, T. E. Exner, J. Chem. Inf. Model. 49 (2009) 84-96.

[48] E. F. Pettersen, T. D. Goddard, C. C. Huang, G. S. Couch, D. M. Greenblatt, E. C. Meng, T. E. Ferrin, J. Comput. Chem. 25 (2004) $1605-1612$. 